\title{
ARTICLES
}

\section{AGRICULTURAL TITHING AND (FLAT) TAX COMPLEXITY}

\author{
Adam S. Chodorow ${ }^{*}$
}

Table of Contents

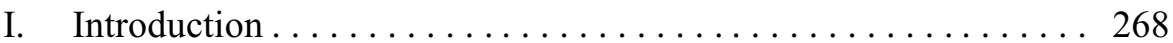

II. Jewish Legal Authority . . . . . . . . . . . . . . . . . . 272

III. Agricultural Tithing . . . . . . . . . . . . . . . . . . 277

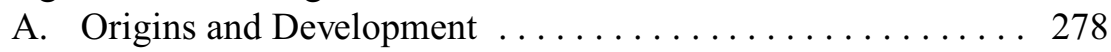

B. Income Definition in Agricultural Tithing . . . . . . . . 279

1. Gross Income . . . . . . . . . . . . . . . . . . 280

a. Source and Scope ................ 280

b. The Realization Requirement ............ 285

c. In-Kind Income Measurement . . . . . . . . . . . . . 287

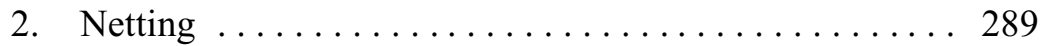

3. Accounting Periods and Timing . . . . . . . . . . . 291

IV. Tithing and Tax Reform .................... 293

A. Reforming the Current Income Tax ............ 293

B. Consumption Tax Complexity ................ 297

1. The Theoretical Approach ................ 300

2. The Practical Approach ................ 302

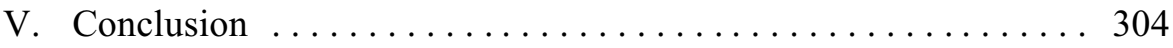

\footnotetext{
* Associate Professor of Law at the Sandra Day O'Connor College of Law at Arizona State University. I would like to thank Miranda Perry, Jon Brose and Todd Toral for pointing me towards the Bible as a source of tax law. I would also like to thank Rabbi Zvi Holland, the Phoenix Community Kollel and Saul Abrams for their patience and perseverance in the face of countless questions regarding halacha and tithing. I would also like to thank Saul Levmore, Ellen April, Marjorie Kornhauser, Henry Ordower, Samuel Levine, Michael Livingston, Victor Fleischer, Larry Zelenak, Yariv Brauner, the members of the Arizona State University Legal Theory Colloquium, and the participants at the Junior Tax Scholars Conference at the University of Colorado, Boulder, for their comments on earlier drafts.
} 


\section{INTRODUCTION}

Tax complexity has been of major concern to legislators and academics almost since the first income tax was enacted in 1913, ${ }^{1}$ and scholars have generated a large and varied body of scholarship on the subject. Some scholars have explored the causes and nature of complexity, ${ }^{2}$ while others have focused on how best to simplify the current income tax, while keeping its major design features in place. ${ }^{3}$ Those interested in more radical reform of the current tax system have seized on the purported complexity of controversial provisions, such as the progressive rate structure and the tax preference for capital gains, to justify the elimination of those features. ${ }^{4}$ More recently, consumption tax advocates have claimed that such taxes are inherently less complex than the income tax, and therefore, we should replace the income tax altogether with some form of consumption tax. ${ }^{5}$ Indeed, Steve Forbes has repeatedly argued that his preferred form of consumption tax is so straightforward that we can calculate our taxes using a simple postcard and abolish the IRS in the process. ${ }^{6}$

1. The issue was apparently raised as early as 1920. See Robert B. Eicholz, Should the Federal Income Tax Be Simplified?, 48 YALE L.J. 1200, 1212 (1939). In 1926 Congress created the Joint Committee on Internal Revenue Taxation for the purpose of considering tax simplification. The committee issued its first report in 1927. See J. Comm. of Internal Revenue Taxation, Report of the J. Comm. on Internal Revenue Taxation, H.R. Doc. No. 70-139 (1927). See Paul R. McDaniel, Simplification Symposium Federal Income Tax Simplification: The Political Process, 34 TAx L. Rev. 27, 27-28 (1978) (summarizing the early efforts and literature on tax simplification).

2. See, e.g., Edward J. McCaffery, The Holy Grail of Tax Simplification, 1990 WIs. L. Rev. 1267 (1990); see also infra Part IV (discussing tax complexity).

3. See, e.g., Steve R. Johnson, The E.L. Wiegand Lecture: Administrability-Based Tax Simplification, 4 NEV. L.J. 573, 589 (2004) (proposing the elimination of one of the two extant passthrough regimes); Deborah H. Schenk, Simplification for Individual Taxpayers: Problems and Proposals, 45 TAx L. Rev. 121, 134-44 (1989) (proposing changes to the provisions dealing with dependency exemptions, filing status, and the child tax credit).

4. See, e.g., Walter J. Blum \& Harry Kalven, Jr., The Uneasy Case for Progressive Taxation, 19 U. Chi. L. Rev. 417 (1952), reprinted in WAlter J. Blum \& Harr Y Kalven, JR., The Uneasy CASE For Progressive TAXATION (1953) (arguing that the progressive rate structure creates significant complexity and should therefore be eliminated).

5. See, e.g., Robert E. Hall \& Alvin Rabushka, The Flat Tax 3 (2d ed. 1995); William D. Andrews, A Consumption-Type or Cash Flow Personal Income Tax, 87 HARV. L. REV. 1113, 1116(1974) (arguing that accretion taxation creates significant complexity that could be avoided in a cash-flow tax system); Joseph Isenbergh, The End of Income Taxation, 45 TAx L. REv. 283, 286 (1990); John K. McNulty, Flat Tax, Consumption Tax, Consumption-Type Income Tax Proposals in the United States: A Tax Policy Discussion of Fundamental Tax Reform, 88 CAL. L. Rev. 2095, 2105 (2000).

6. Steve Forbes, Flat Tax Revolution: Using a Postcard to Abolish the IRS 59 (2005). 
As efforts to replace the income tax have gathered steam, a number of scholars have attempted to test the claims that a consumption tax really would be less complex than the current income tax. ${ }^{7}$ Because income-based consumption taxes appear ascendant at the moment, much of the scholarship on tax complexity and consumption taxation has focused on such systems. ${ }^{8}$ To date, such scholarship has been largely theoretical and speculative in nature, as we do not know what form such a tax might take. The general conclusion, even from those who prefer consumption taxation to income taxation, is that in the real world, income-based consumption taxes will be more complex than Mr. Forbes would have us believe. ${ }^{9}$

This article approaches the question of tax complexity from a completely different perspective. Rather than imagine a hypothetical income-based consumption tax and speculate as to its implementation, I turn instead to study an actual tax of this type that has existed for over 2,500 years: biblical tithing. Literally, a "tithe" is one-tenth or 10 percent. When used as a verb, it refers to the practice of giving money or property for religious purposes and is now commonly used even when the amount set aside is not 10 percent. $^{10}$ Tithes have been and were in biblical times levied on various forms of income. This article focuses on agricultural tithing, which was required by Deuteronomy 14:22, which provides: "You shall tithe the entire crop of your planting, the produce of the field, year by year." 11

Generally, agricultural tithing has not been recognized as a form of taxation. ${ }^{12}$ Consequently, American tax scholars have all but ignored it. ${ }^{13}$

7. See, e.g., Michael J. Graetz, Implementing a Progressive Consumption Tax, 92 HARV. L. Rev. 1575, 1578 (1979); David A. Weisbach, Ironing out the Flat Tax, 52 STAN. L. Rev. 599, 612 (2000); David A. Weisbach, Does the X-Tax Mark the Spot?, 56 SMU L. Rev. 201, 202 (2003); Daniel Shaviro, Simplifying Assumptions: How Might the Politics of Consumption Tax Reform Affect (Impair) the End Product? 1-3 (New York Univ. Law and Econ. Research Paper Series, Working Paper No. 06-17, 2006), available at $\mathrm{http}: / / \mathrm{ssrn} . \mathrm{com} / \mathrm{abstract}=896160$.

8. Another reason for this focus is that most states and a significant number of foreign countries have some form of transaction based consumption tax, such as a retail sales tax or value added tax. Thus, the details of implementation and issues that arise in such systems are widely known.

9. Graetz, supra note 7, at 1578; Weisbach, Ironing out the Flat Tax, supra note 7, at 661-64; Weisbach, Does the X-Tax Mark the Spot?, supra note 7, at 201.

10. Webster's Encyclopedic Unabridged Dictionary of the English Language (Portland House, New York 1989).

11. All Bible quotations are from The Stone Edition of the Tanach, published by the Mesorah Heritage Foundation in 1996 as part of the ArtScroll Series.

12. Just what constitutes a "tax" is a matter of some debate. From an economic perspective, any cost the government imposes can be considered a tax, including fees and even regulation. The legal definition of a tax is more limited, but somewhat flexible. While tithing may not qualify as a tax under some definitions, it operates as a tax in most regards. For a discussion of how one defines a tax, see VICTOR 
Nonetheless, tithing can be seen either as a simple income tax, where the definition of income is limited to agricultural produce, or as a simple incomebased consumption tax, where consumption is measured indirectly via the proxy of income (i.e., produce) and returns to capital are excluded from the tax base. Unlike many of the income-based consumption tax proposals currently under consideration, tithing eschews progressivity; allows no deductions; ignores complex financial transactions; and contains no provisions extraneous to the task of income measurement. As such, it provides an excellent opportunity to explore real-world income-based taxation in its most basic form and to ascertain whether stripping controversial provisions, such as progressivity, from the current income tax or replacing the income tax completely with an income-based consumption tax can deliver on the simplicity that proponents of such measures promise. ${ }^{14}$

In the debate over whether to reform the current income tax or replace it entirely with a consumption tax, Professor Steve Johnson has warned that we need to be wary of "fanciful notions of a new Promised Land of taxation." 15 By focusing on taxation in the Promised Land itself, I hope to show that any income-based tax, whether a true income tax or an income-based consumption tax, will necessarily be complex. Questions of income inclusion, tax avoidance, and timing are unavoidable in any income-based system, and those issues alone generate significant complexity. This conclusion has implications both for the reform of our current income tax and for those who claim that income-based consumption taxation will solve the problem of tax complexity. If complexity exists in this fairly straight-forward tax system, it will certainly arise in any of the more sophisticated income tax or incomebased consumption tax systems currently under discussion. This is not to suggest that eliminating progressivity or switching to a consumption tax might

Thuronyi, Comparative Tax Law 45-59 (2003).

13. Indeed, comparative studies of taxation are rare in American tax scholarship, even with acknowledged income tax systems. To the extent that reference is made to a foreign income tax system, it is normally by a tax historian. See, e.g., Richard J. Joseph, The Origins of the American Income TAX, the Revenue ACt of 1894 AND its Aftermath (2004) (providing an historical look at the roots of income taxation). Even then, the goal is normally to identify the possible inspirations for our own decision to adopt an income tax and not to explore its features. Id. Nonetheless, exceptions exist. See, e.g., HugH J. Ault \& Brian J. Arnold, Comparative Income Taxation: A Structural Analysis (2d ed. 2004) (comparing solutions to income tax design problems of nine industrialized countries); THURONYI, supra note 12 .

14. The focus here on income-based consumption taxes is not meant to suggest that we should prefer transaction-based consumption taxes, such as a national sales tax or value added tax. Rather the relative complexity of transaction-based consumption taxes is beyond the scope of this article.

15. Johnson, supra note 3 , at 578 . 
not provide some simplification benefits. Rather, it is to caution that the impulse to effect radical changes to the current tax system in the name of simplification may, like the proverbial fourth marriage, reflect a triumph of hope over experience.

In focusing on the laws of tithing, I confess to an ulterior motive as well. Jewish law is somewhat impenetrable to those unfamiliar with its structures and logic, and I hope to make this material accessible to others who might be interested in exploring the laws of tithing. Yet, while American lawyers are generally unfamiliar with the Judaic tradition, American legal scholarship contains a long and rich tradition of looking to Jewish law for insights when analyzing U.S. law and its legal system. ${ }^{16}$ I hope also to contribute to and perhaps deepen this body of work.

This article is the first in a series of articles exploring the relationship between tithing and taxation. Judaism imposes two different tithing obligations, ${ }^{17}$ each of which illuminates taxation in different ways. The first

16. Areas where scholars have compared Jewish and American law are too numerous to list, but they include health law, criminal law, tort law, constitutional law, and legal ethics. A search for the term "Jewish Law" in the Westlaw "law review" database yields over 1,600 hits. For a summary of Jewish law references in American legal scholarship up to 1993, see Suzanne Last Stone, In Pursuit of the Counter-Text: The Turn to the Jewish Legal Model in Contemporary American Legal Theory, 106 HARV. L. REv. 813, 814-21 (1993).

17. In fact, Judaism imposes three tithing obligations. However, with the destruction of the Temple in Jerusalem in 70 C.E., the practice of maaser behaima (relating to animals and described in Leviticus 27:32) is no longer observed. Rambam, Mishneh Torah, Karbanos, Bekhoros 6:2. For a good translation of the Mishneh Torah, see Moses Maimonides, The Code of Maimonides (Julian Obermann et al. eds., Jacob J. Rabinowitz et al. trans., Yale University Press 1949). Rambam is a commonly understood nickname for Rabbi Moses ben Maimon [hereinafter RAmBAM]. For further explanation, see infra note 49. The Torah imposes a number of obligations with regard to agriculture that are related to, but not part of, the tithing obligation. I discuss those obligations here only to the extent that they implicate tithing and income definition. In addition, the Torah also imposes obligations regarding gifts to the priests, including the offering of first fruits and first born animals. See, e.g., Exodus 13:2, 22:28-29. Such obligations are beyond the scope of this article.

The Mishneh Torah is separated into books, which are further separated into numerous treatises. In Hebrew, sefer means "book." The following translations for Mishneh Torah books may be helpful when reviewing the rest of this article:

$\begin{array}{ll}\text { Zaraim: } & \text { Book of Agriculture } \\ \text { Korbanos: } & \text { Book of Sacrifices } \\ \text { Zemanim: } & \text { Book of Seasons } \\ \text { Moreover, the following translations for treatises within these Mishneh } & \text { Tithes } \\ \text { Maaserot: } & \text { Firstlings } \\ \text { Bekhoros: } & \text { Leavened and Unleavened Bread } \\ \text { Chometz U'Matzah: } & \text { Second Tithe and Fourth Year's Fruit } \\ \text { Maaser Sheni Neta Revai: } & \end{array}$


practice, called masserot,$^{18}$ applies to agricultural produce grown in the land of Israel and is the subject of this article. The second, called maaser kesafim,,$^{19}$ applies to income from whatever source derived and is strikingly similar to our current income tax. This practice is the subject of my second article on tithing, Maaser Kesafim and the Development of Tax Law, ${ }^{20}$ in which I explore the ways culture and context affect income definition. The third article in this series will explore questions of progressivity as they relate to Jewish tithing practices. Religious values have long played a role in shaping our social policies, including decisions regarding progressivity. ${ }^{21} \mathrm{In}$ considering such issues, it may help to explore how religious tax systems themselves have dealt with this issue. ${ }^{22}$

This article is organized as follows: Part II describes the provenance and structure of the Jewish legal system. Part III describes the laws of agricultural tithing. Part IV briefly describes the tax scholarship on complexity and consumption taxation and then analyzes the tithe in light of such scholarship. Part V concludes.

\section{Jewish Legal Authority}

To understand the laws regarding tithing, one must have some understanding of the provenance and structure of the Jewish legal tradition, as well as the authorities that compose it, commonly referred to as halacha. ${ }^{23}$

18. Maaserot translates literally as "tithes." Deuteronomy 14:22 established the obligation to tithe.

19. Kesef means silver or money, and this phrase translates as "a tenth of money."

20. 8 Fla. Tax Rev. 153 (2007).

21. For instance, in Alabama, proponents of tax reform relied heavily on Christian principles as the basis for reform. See, e.g., Shailagh Murray, Divine Inspiration: Seminary Article in Alabama Sparks TaxCode Revolt, Wall St. J., Feb. 12, 2003, at A1 (discussing Susan Pace Hamill, An Argument for Tax Reform Legislation Based on Judeo-Christian Ethics, 54 ALA. L. REv. 1 (2002)). Professor Hamill argues that Alabama's tax structure violates the moral principles of Judeo-Christian ethics because of its regressive burden that punishes low-income Alabamians and its grossly inadequate revenues that fail to cover even the minimum needs of our most vulnerable citizens. Id. at 51-66. More recently, Professor Hamill has turned her attention to the Federal income tax system. See Susan Pace Hamill, An Evaluation of Federal Tax Policy Based on Judeo-Christian Ethics, 25 VA. TAx REv. 671, 673-710 (2006) (concluding that the moral principles of justice of Judeo-Christian ethics require an adequate level of revenues supporting the reasonable opportunity of all Americans to reach their divinely inspired potential and that such revenues be raised under a tax structure that imposes a moderately progressive burden as levels of income and wealth increase).

22. Among other things, I hope to explore how one can square the claim that Judeo-Christian values require progressive taxation with the fact that God Himself apparently only asked for a flat 10 percent.

23. More formally, halacha refers to Judaism's normative rules and encompasses both those that govern interpersonal relationships and those that govern the relationship between mankind and God. See 1 Menachem Elon, Jewish Law: History, Sources, Principles 93-104 (Bernard Auerbach \& Melvin 
This Part briefly describes the literal account of the origins and structure of Jewish law drawn from the Bible and later documents. ${ }^{24}$ I have chosen the literal account because I am interested in the development of the law by those who believe in its divine origins and who grant its internal logic. ${ }^{25}$

God summoned Moses to the top of Mount Sinai to give him the law. When he descended, Moses brought with him not only the Ten Commandments, but also the law that was recorded in the Torah, ${ }^{26}$ and a detailed explanation of how the laws were to operate. ${ }^{27}$ Moses transcribed the $\mathrm{Torah}^{28}$ and orally relayed the remaining law to the Jewish leaders, who passed it down from generation to generation in an oral tradition. ${ }^{29}$ Initially, writing the oral tradition was prohibited because the Jewish leaders believed that doing so would limit and distort the law. ${ }^{30}$

J. Sykes trans., 1994) (1988).

24. For a concise account of the development of Jewish law from the time of Moses to the time of the Talmud, see Rambam, Mishneh Torah, Hakdama. For a more detailed description of the nature and sources of Jewish law, see 1-2 ELON, supra note 23. Most of the sources cited herein have been translated into English. Where appropriate, I have indicated in the footnotes the translations on which Ihave relied.

25. For instance, based on their beliefs regarding the Torah's provenance, many religious authorities read the Torah as a unified whole, where all parts can be read together as consistent, even though a casual reader could point to numerous apparent inconsistencies. For example, in Genesis, Adam is told that he will die on the day he eats from the Tree of Knowledge. Genesis 2:17. Nonetheless, he is also reported to have lived to the age of 930. Genesis 5:5. To resolve this apparent conflict, Rabbi Moshe ben Nachman (Ramban or Nachmanides) concluded that "die" meant "become susceptible to death." RABBI Moses BeN Maimon, Commentary on the Torah, Genesis, Genesis II, Bereshith 2:17 (Rabbi Charles B. Chavel trans., 1971). Others determined that a "day" for God is 1,000 earth years (based on Psalm 90:4), and therefore, when Adam died at age 930, he died on the same day on which he ate the forbidden fruit.

Significant differences exist between the literal and academic accounts. For instance, religious tradition insists that Moses wrote the Torah (including the description of his own death), RAMBAm, MishneH TORAH, Hakdama, while academic scholars contend the Torah is an amalgam of different codes written at different times and ultimately pulled together long after the time of Moses. For an academic recounting of the provenance and development of Jewish law, see AN INTRODUCTION TO THE HISTORY AND SourCes of JEWISH Law (N.S. Hecht et al. eds., 1996). Significant differences of opinion and belief regarding the creation and significance of the law exist within the Jewish community. Depending on the tradition, religious communities fall somewhere along the spectrum between the literal and academic accounts. Exploring those differences is beyond the scope of this article.

26. The Torah consists of the first five books of the Bible(Genesis, Exodus, Leviticus, Numbers and Deuteronomy) and is sometimes referred to as the Pentateuch (meaning "5 books" in Greek), the "written Torah" or the Chumash.

27. Religious Jews refer to this oral tradition as the oral Torah and view it together with the Torah as a unitary revelation of God's law. Rambam, Mishneh Torah, Hakdama.

28. Deuteronomy 31:9, 31:24; Rambam, Mishneh Torah, Hakdama.

29. See Rambam, Mishneh Torah, Hakdama, for a description of the transmission of this oral tradition from Moses all the way down to the time of the Talmud.

30. Babylonian Talmud, Temurah 14b. All citations to the Babylonian Talmud refer to The Shottenstein Edition, published by ArtScroll as part of an effort by the Mesorah Heritage Foundation. 
Although God's revelation to Moses ended on Mount Sinai, the development of the law continued. This took the form of both interpretation of the Torah and oral tradition, and the creation of additional laws. ${ }^{31}$ While it was forbidden to add to or detract from the Torah, ${ }^{32}$ rabbis were empowered to, and did, create a number of new rules to "make a fence for the Torah," 33 thereby preventing the people from inadvertently violating Torah commandments. ${ }^{34}$

In the first and second centuries C.E., as the Jewish people spread throughout the known world, it became clear that the oral tradition could not be maintained as such. ${ }^{35}$ Thus, about 200 C.E., Rabbi Judah ha-Nasi (also known as Rabbenu Hakadosh) created the Mishnah, a written record of the tradition redacted from the personal notes of those who had studied the law. It was organized into "tractates" on specific subjects and reflected the different opinions of the rabbis whose notes the editor used. ${ }^{36}$ The Mishnah contained both the law revealed on Mt. Sinai and the rabbinic laws created since then, though it did not explicitly distinguish between the two. Consistent with the notion that the tradition should not be committed to writing lest it be limited or otherwise corrupted, the Mishnah was more in the nature of head notes meant to jog the reader's memory than an attempt to set forth the law in its entirety. Other significant writings from this period include the Tosefta, ${ }^{37}$ a supplement to the Mishnah, and interpretive commentaries on the Torah, generally referred to as midrashim (singular midrash) ${ }^{38}$

31. For a discussion of the sources of Jewish law and the differences between interpretation and legislation, see Samuel J. Levine, An Introduction to Legislation in Jewish Law, with References to the American Legal System, 29 Seton Hall L. Rev. 916 (1999) (exploring the dual role of rabbis as interpreters of the Torah and enactors of rabbinic laws). See also 1-2 Elon, supra note 23.

32. Deuteronomy 4:2.

33. See The Mishnah, Abot 1:1 (Jacob Neusner trans., 1988); see also Rambam, Mishneh Torah, Hakdama.

34. For example, the Torah prohibits one from eating leavened bread after mid-day on the eve of Passover. Exodus 12:15-16; Babylonian Talmud, Pesahim 4b-5, 11b. On a cloudy day, it might be difficult to tell time. Accordingly, the rabbis created a rule that prohibited one from eating leavened bread from the fifth hour after daybreak, thus reducing the chance of inadvertently consuming such bread. See Rambam, Mishneh Torah, Zemanim, Chometz U'Matzah 1:9.

35. See Babylonian Talmud, Temurah 14b; Rambam, Mishneh Torah, Hakdama.

36. For an English translation of the Mishnah, see the ArtScroll version.

37. For a translation of the relevant tractate of the Tosefta, and commentary thereon, see MART IN S. Jaffee, Mishnah's Theology of Tithing (1981). For a discussion of the Tosefta's provenance and significance, see 3 ELON, supra note 23 at 1078-81.

38. These commentaries sought to construe the Torah as a consistent whole by giving meaning to every word. For a description of the origins of the term midrash and the interpretive tradition it represents, 
In time, religious leaders determined that to preserve the oral tradition they needed a more detailed compilation than the Mishnah. Accordingly, between 400 and 600 C.E., they created the Gemara. ${ }^{39}$ The Gemara restates the Mishnah and then adds additional discussions of the law. It follows the Mishnah's organization, but actually consists of two books, the Jerusalem Talmud and the Babylonian Talmud. ${ }^{40}$ Like the Mishnah, the Gemara recounts discussions and debates among prominent rabbis regarding the oral tradition, preserving both the majority and minority opinions. ${ }^{41}$ The Gemara is generally accepted as authoritative by the entire Jewish people, and its creation marks the end of the first period of the development of Jewish law. ${ }^{42}$ Insofar as the Torah, the Mishnah, and the Gemara purport to relate the law given to Moses on Mount Sinai, they sit atop the Jewish legal hierarchy, much as our own Constitution sits atop the U.S. legal hierarchy. ${ }^{43}$ However, unlike the Constitution, the Torah and Talmud cannot be amended or changed in any way. ${ }^{44}$

see Reuven Hammer, Sifre on Deuteronomy 1-21 (1986).

39. Gemara is the Aramaic word for teaching. Consistent with the notion that the oral tradition would be impaired if committed to writing, religious Jews contend that one cannot understand the Gemara by reading it in isolation. Rather, one must still engage in an oral learning process to appreciate the full extent of the law. See Ramban, Commentary on the Torah, Introductory Verses.

40. The phrase "study Talmud" usually refers to both the Mishnah and Gemara, whereas the term "the Talmud" usually refers to one of the two versions of the Gemara. Jerusalem and Babylon were the two great centers of Jewish life during this period. Although there is some overlap between the two Talmuds, the Jerusalem Talmud covers in great detail the laws that apply solely to activities undertaken in Israel. Such coverage is missing from the Babylonian Talmud, where those rules were less relevant. The effort to compile the Jerusalem Talmud ceased when the authors were expelled from Israel, and therefore it is shorter than the Babylonian Talmud. It is also less authoritative. See 3 Elon, supra note 23 at 1087-98.

Perhaps the most accessible translation of the Babylonian Talmud is The Shottenstein Edition, published by ArtScroll as part of an effort by the Mesorah Heritage Foundation.

41. Significant academic debate exists regarding the reasons for preserving these minority opinions, the weight to be given to them, and what the practice reveals about the nature of the Jewish legal system. See generally Stone, supra note 16 (discussing Jewish legal traditions).

42. For a description of the different periods of Jewish law, see 1 Elon, supra note 23, at 39-45. The Jewish community in Ethiopia split off from the larger Jewish community before the Talmud was created. The Talmud did not become part of their tradition until their recent integration into modern Jewish society in Israel. See Letters from Beyond the Sambatyon: The Myth of the Ten Lost Tribes (MAXIMA New Media Ltd. CD-ROM, 1997), excerpt available at http://www.pbs.org/wgbh/nova/israel/ losttribes3.html\#beta.

43. See, e.g., Rambam, Mishneh Torah, Hakdama.

44. Evidence of the inability to amend the Torah can be seen in the Talmudic story of the Oven of Aknai. Babylonian Talmud, Bava Mezia 59b. In this story, Rabbi Eliezer disagreed with the sages of his time over whether an earthenware oven could become unclean. Eventually, to resolve the debate, Rabbi Eliezer called on God to affirm his position, and God obliged. Rather than concede the point, the sages responded that the Torah "is not in Heaven," meaning that man is entrusted with the interpretation of the Torah, and even later revelations cannot change this. Id. For a discussion of this story and its meaning with 
This is not to say that the development of the law ceased with the completion of the Talmud. Rather the nature of the enterprise changed from recording God's law to interpreting it, commenting on it, and applying it to everyday life. ${ }^{45}$ Included among these efforts are numerous commentaries on the Torah and Talmud, ${ }^{46}$ as well as a rich responsa literature, called She'elot U'Teshuvot or Shu't. ${ }^{47}$ Over the centuries, the thorniest legal questions were posed to the most respected rabbis, who often published their responses, much like courts publishing their opinions. Indeed, this literature is analogous to our own case law in that it represents the legal interpretation of those entrusted with construing the law.

Finally, several efforts to codify the law have been made, the most important of which for our purposes are the Mishneh Torah ${ }^{48}$ by Rabbi Moshe ben Maimon (1135-1204) (Maimonides or Rambam ${ }^{49}$ ); the Arbah Turim, by Rabbenu Yaakov ben Asher (1269-1340) (the Tur) ${ }^{50}$ and the Shulchan Aruch,

regard to the interpretive/legal enterprise, see Stone, supra note 16, at 854-65.

45. In the course of this enterprise, Jewish authorities developed a number of interpretive canons that closely resemble those used in the U.S. legal system. For a discussion of the U.S. canons of statutory interpretation, see Karl Llewellyn, Remarks on the Theory of Appellate Decision and the Rules or Canons About How Statutes Are to be Construed, 3 VAND. L. REV. 395 (1950). For a concise listing and description of the Jewish interpretive canons, see Note, Looking to Statutory Intertext: Toward the Use of the Rabbinic Biblical Interpretive Stance in American Statutory Interpretation, 115 HARV. L. REV. 1456 (2002). See also Samuel J. Levine, Jewish Legal Theory and American Constitutional Theory: Some Comparisons and Contrasts, 24 Hastings Const. L.Q. 441 (1997).

46. For example, during the twelfth century, Rabbi Shlomo Yizchaki (Rashi) (1090-1 156) created a detailed running commentary on the Talmud. His descendants, both literally and intellectually, were called the Tosafists, who created a second commentary that provided cross references to other parts of the Talmud. These commen taries are traditionally printed with the text of the Talmud. See 3 ELon, supra note 23 , at $1116-23$.

47. For a discussion of the nature and role of responsa literature, see Berachyahu Lifshitz, The Legal Status of the Responsa Literature (1988), translated in Authority, Process And Method: StUdies IN JEWISH LAw 59 (Hanina Ben-Menahem \& Neil S. Hecht eds., 1998) [hereinafter StUdieS IN JEWISH LAw]; see also Zerah Warhaftig, Precedent in Jewish Law (1979), translated in STUdiEs In Jewish LAw, supra, at 1 (discussing whether responses were or should be binding on judges or rabbis).

48. The Mishneh Torah was an attempt to organize all of the laws in one place and was intended to be the one book, aside from the Torah and Talmud, to which people would need to refer. RAMBAM, Mishnah ToRAh, Hakdama. It departs from the tradition in the Mishnah and Talmud of presenting dissenting opinions. It is also organized differently.

49. Many of the most famous and respected rabbis were given nicknames. These names are often based on the rabbi's most significant book or his initials. For instance, "Rambam" comes from Rabbi Moshe ben Maimon's initials RMBM. In contrast, Rabbi Asher's most famous work is the Arbah Turim, and he is often referred to as "the Tur."

50. The Tur was the third son of Rabbenu ben Yechiel Asher (1250-1327) (The Rosh), one of the most influential legal scholars of his time. The Tur is credited with having organized the law into four distinct columns (Turim), each named after one of the four rows of precious stones covering the High Priest's breastplate. Unlike the Mishneh Torah, the Arbah Turim (the Four Columns) presented differing 
by Rabbi Yosef Karo (1488-1575). ${ }^{51}$ As with the Torah and Talmud, numerous rabbis have written commentaries on these codes. ${ }^{52}$

As a result of the structure and development of Jewish law, religious obligations in Judaism can have three sources: the Torah (de-oraita, ${ }^{53}$ the rabbis (de-rabbanan), ${ }^{54}$ and custom (minhag). The source of the obligation matters because it dictates the extent to which the obligation must be observed. Obligations based on the Torah and the oral tradition have the force of law and must be strictly observed. Rabbinic obligations carry similar weight, but the rules are construed somewhat more leniently. Obligations based on custom carry the least weight and allow for the greatest variation. ${ }^{55}$ Thus, the nature of the obligation may affect the development and interpretation of a given law or command.

\section{Agricultural Tithing}

Before the Jewish people entered Canaan to take possession of the land promised to Abraham, Isaac, and Jacob, Moses revealed to them the laws that were to govern how they lived once there. ${ }^{56}$ These laws formed a web of social and religious obligations designed to ensure the survival and health of the Jewish people. Many of these laws imposed obligations with respect to agriculture. The obligation to tithe is one of these and is based primarily on the commandment: "You shall tithe the entire crop of your planting, the produce of the field, year by year." ${ }^{157}$ Tithing fulfills three different objectives

views and then chose among them. It is organized according to subjects, as opposed to following the Talmud, but its organization differs from that Rambam used in the Mishneh Torah. See 3 Elon, supra note 23. at $1277-1302$.

51. Initially, Rabbi Karo wrote a commentary on the Arbah Turim, called the Beth Yosef. He later distilled the Shulchan Aruch from this commentary. Given its genesis as a commentary on the Tur's work, it followed the Tur's organization. The Shulchan Aruch represented the codification of Sephardic law and was initially rejected within the Ashkenazi community. Rabbi Moshe ben Yisrael Isserles (c. 1525-1572) (Rema) created a gloss on the Shulchan Aruch, which is credited with causing the Shulchan Aruch to be accepted within the Ashkenazi community. See 3 Elon, supra note 23, at 1309-66. (1884).

52. See, e.g., Yechiel Michal Epstein, The Aruch haShulchan (Yair Hoffman trans., 1997)

53. De-oraita is an Aramaic phrase meaning from the Torah.

54. De-rabbanan is an Aramaic phrase meaning from or of the scholars.

55. For a discussion of the role of custom in Jewish law, see 2 Elon, supra note 23, at 880-944.

56. Deuteronomy 1:1, 4:1. In addition, Moses divided the land among the tribes of Israel. Numbers 33:50-55.

57. Deuteronomy 14:22. Tithing is referred to at numerous other places in the Bible. See, e.g., Malachi 3:10 ("Bring all the tithes into the storage house. ..."); Leviticus 27:30 ("Any tithe of the land, of the seed of the land, of the fruit of the tree, belongs to HAshem; it is holy to HAshem."); Proverbs 3:9 
central to Jewish life. The first is to support the Levites, ${ }^{58}$ the second is to bring people regularly to a place God would determine-eventually the Temple in Jerusalem - to celebrate God's blessings; the third is to support the poor. $^{59}$

\section{A. Origins and Development}

The Torah lists eight obligatory offerings associated with produce grown in Israel. Four obligations apply during the harvest. First, farmers must leave the corners of their fields unharvested so that the poor can partake of this produce (called pe'ah). ${ }^{60}$ Second, if produce falls to the ground during the harvest, it is to be left for the poor (called leket). ${ }^{61}$ Third, if the farmer leaves a pile of produce in the field, he must leave it for the poor (called shikhah).$^{62}$ Finally, the first fruits are to be marked and brought to Jerusalem (called bikurim) ${ }^{63}$

Four obligations apply after the harvest. The first (called terumah) is a small offering (ranging from $1 / 40$ th to $1 / 60$ th of the produce) that was to be separated and given to a Cohen (plural Cohenim), who was to eat it while ritually pure. ${ }^{64}$ The second (called challah) is a small offering of dough, which is also to be separated and offered to a Cohen, who is to eat it while ritually pure. ${ }^{65}$ The third and fourth post-harvest offerings are the tithes, described more fully below. Food is considered tevel and may not be consumed as part of a meal until the terumah and tithes have been separated. ${ }^{66}$

Deuteronomy 14:22 establishes the obligation to tithe and identifies two different tithes. The first is called maaser rishon and was to be given to a

("Honor HASHEM with your wealth, and with the first of all your produce. ..."). Hashem literally means "the Name" and is used as a euphemism for God.

58. The Levites were the descendants of Levi (the son of Jacob and Leah) and served as God's special servants. See Numbers 3:5-10. They were excluded from the division of land and therefore depended on others for their sustenance. In lieu of land, the Levites were given cities in which to live. See Numbers 35:1-8.

59. Deuteronomy 14:22-29.

60. Leviticus 19:9, 23:22.

61. Id. at 19:10.

62. Deuteronomy 24:19.

63. Id. at 26:1-11.

64. Id. at 18:4; Leviticus 22:1-15. Cohenim were the descendants of Aaron, Moses's brother, and served as God's priests. Leviticus 1,8 . With the destruction of the temple, it is not possible for a Cohen to be ritually pure. This offering is now separated and burned. See Joseph Karo, Shulchan Aruch, Yoreh De'ah 331:19.

65. Numbers 15:20. This offering is also now burned.

66. Rambam, Mishneh Torah, Zaraim, Maaserot 1:5. 
Levite. ${ }^{67}$ The second tithe was to be consumed at the Temple in Jerusalem or given to the poor, depending on the year to which the tithe belonged. The Jewish calendar is based on a 7-year cycle. In years 1, 2, 4, and 5, the farmer was to take this second tithe (called maaser sheni) to Jerusalem and eat it before the Temple. ${ }^{68}$ In years 3 and 6, the farmer was to give this second tithe (now called maaser ani) to the poor. ${ }^{69}$ In year 7 , known as the sabbatical year, the land was to lie fallow, obviating the need for tithes. ${ }^{70}$

\section{B. Income Definition in Agricultural Tithing}

At first blush, agricultural tithing and our income tax would appear to have little in common. Our tax laws are the product of a complex political process and are designed primarily to raise revenue for funding government spending. The main concerns of the tax laws are equity, efficiency, and simplicity, though the tax laws also contain rules designed to carry out social policy objectives unrelated to the income tax, ${ }^{71}$ as well as rules designed to provide benefits to special interests. ${ }^{72}$ As a result, our tax system incorporates insights from modern economic theory and philosophy, as well as provisions not strictly necessary for income measurement. ${ }^{73}$

In contrast, the obligation to tithe is a command from God made millennia ago when economies were primarily agricultural and when economic science, indeed the very notion of science itself, either did not exist or was in its

67. Deuteronomy 14:29; Leviticus 27:30. When the Levites refused to leave Babylon and return to Israel to help construct the Second Temple, the Prophet Ezra punished them by taking away their tithe. Bablyonian Talmud, Kethuboth 26(a); Rambam, Mishneh Torah, Zaraim, Maaserot 1:4.

Interestingly, the terumah and first tithe were not due to any specific Cohen or Levite. The donors' ability to decide who received the offering created a market place, where those who wished to receive the offerings had to consider how their behavior or rulings would affect potential donors. BABYLONIAN TALmud, Chulin 130.

68. Deuteronomy 12:17-18, 14:23. Those who lived far from the Temple in Jerusalem were authorized to redeem the tithe and save the proceeds until they could travel to Jerusalem, purchase food, and consume it there. Id. at 14:24-26.

69. See id. at 14:28-29.

70. Exodus 23:11; Leviticus 25:1-7. Any food that spontaneously grew in the fields was to be left to the poor and animals. Exodus 23:11; Leviticus 25:7. Special rules exist for dealing with the treatment of fruits and nuts that grow on vines and trees in the seventh year, absent any planting effort on behalf of the farmer. See generally The Mishnah, Sheviis 4, 7, 8.

71. Examples include the exclusion of gain on the sale of a principal residence (I.R.C. § 121 (2000)), the home mortgage interest deduction (I.R.C. $\S 163(\mathrm{~h})(3)$ ), and the tax-free receipt of health insurance (I.R.C. § 125).

72. For a discussion of public choice theory, see, e.g., Daniel A. Farber \& Philip P. Frickey, The Jurisprudence of Public Choice, 65 TEx. L. REv. 873 (1987).

73. E.g., the taxation of imputed interest. I.R.C. $§ 7872$ (2000). 
infancy. ${ }^{74}$ As God's law, it is immutable, thus precluding the incorporation of new insights and making it impervious to special interest "politicking." Nonetheless, despite these vast differences, tithing operates as an incomebased tax insofar as the amount of the tax is determined as a percentage of one's income. As described in the introduction, tithing can be conceived of as either a simple income tax, devoid of many of the complicating factors present in our modern income tax, or as an income-based consumption tax, similar in its basic structure to those currently being proposed for use in the United States.

Stanley Surry has noted that any income-based tax system will struggle with certain universal issues, such as measurement and timing. ${ }^{75}$ Agricultural tithing is no exception. While the Torah sets forth the obligation to tithe, the Mishnah, Tosefta and Talmud set out the details of implementation, much like the Treasury regulations do in the federal income tax system. While the specific questions and answers are different from those posed in the context of the federal income tax, the underlying issues are the same, including: (1) What should be included in gross income; (2) what deductions, if any, should be allowed against gross income; and (3) how should accounting periods be managed? What emerges from these texts is a complicated and sophisticated income definition that belies the apparently simple requirement that one tithe "the entire crop of your planting, the produce of the field, year by year." $" 76$

\section{Gross Income}

\section{a. Source and Scope}

Generally speaking, tithes are due on "produce" grown in "fields" in "Israel." 77 Despite the lack of apparent ambiguity, each of the words contained in quotation marks requires further definition. This section explores

74. Law and economics scholars would no doubt argue that humans act intuitively in economically efficient ways and therefore these rules implicitly embody economically rational choices. I do not intend to take on this claim, but rather to note that explicit consideration of economics was not prevalent when these laws were developed.

75. Stanley Surry, Complexity and the Internal Revenue Code: The Problem of the Management of Tax Details, 34 Law \& Contemp. Probs. 673, 673-83 (1969).

76. Deuteronomy 14:22.

77. Deuteronomy 14:22. While Deuteronomy 14:22 does not explicitly set forth that only produce grown in Israel is subject to tithing obligations, the laws Moses revealed govern how the Jews were to live once they took possession of the Promised Land (i.e., Israel). See Deuteronomy 4:1. 
how the religious authorities defined these terms, revealing in the process a complexity inconsistent with the apparent simplicity of a flat-rate incomebased tax.

The first question is: What counts as produce? This can be broken down into two subsidiary questions, the first of which is whether this includes all agricultural products, or whether it is limited to that which grows in the soil. Deuteronomy 14:22 literally instructs that one tithe "the entire crop of your planting, the produce of the field. ..." Nonetheless, halachic sources reveal some controversy. For instance, the Sifre on Deuteronomy ${ }^{78}$ raises the question of whether the tithing obligation applies to agricultural products such as milk and honey. Although the broader reading might be more equitable, it concludes that Deuteronomy's explicit reference to the "fields" limits the obligation to a subset of agricultural products. ${ }^{79}$

The second question is whether "produce" includes everything that grows in the soil, or only a subset thereof.$^{80}$ Deuteronomy 14:23 instructs that one is to consume "the tithe of your grain, your wine, and your oil" at a place God designates (i.e., the Temple in Jerusalem), and a number of rabbis questioned whether this list acts as a limitation on what is subject to tithe. The Sifre on Deuteronomy concludes that it does not, based on the broad obligation to tithe in Deuteronomy 14:22, and the statement in Leviticus 27:30 that the tithe of the land "whether of the seed of the land or the fruit of the tree" is holy. ${ }^{81}$

The Mishnah tractate Maaserot begins with the statement that the law of tithes applies to "anything which is (1) food, (2) cultivated, (3) and which

78. The Sifre was a midrash from the time of the Mishnah and included commentary on both Numbers and Deuteronomy.

79. See Sifre: A Tannaitic Commentary on the Book of Deuteronomy, Piska 105 (Reuvan Hammer trans., 1986) (1545) [hereinafter SIFRE]. In contrast, another passage from the Sifre, extant only as quoted by Tosafoth, construes this same language to impose an obligation on all income, regardless of whether it is agricultural or produced by other means. This passage concludes that the word "entire" in the phrase "the entire crop" was superfluous. Accordingly, it invests the word with the meaning that all income is subject to tithe, and not just agricultural produce. See ToSAFOTH, Taanith 9a, translated in MAASER Kesafim: On Giving a Tenth to Charity 20 (Cyril Domb ed., 2d corr. ed., 1982) [hereinafter MaAser Kesefim]. See also Shnei Luchot HaB'rith Deuteronomy 28:3 (2000), YitzchaK Abuhav, Menoras Hamaor Deuteronomy 28:3 (Rabbi Yaakov Yosef Reinman trans., 1982), and Metsudah Misdrash Tanchuma Devorim (Rabbi Avrohom Davis trans., 2004) (all concluding that, insofar as those in the cities and fields are blessed, tithes should be owed on all income).

80. For a discussion of the controversy over what produce is covered and the type of obligation that applies, see Rabbi Mordecai Rabinovitch, The Mishnah: Seder Zaraim Vol. IV(b): Maaseros/ MAASER SHEni 5 (Rabbi Reuvein Dowek ed., 2003).

81. Sifre, Piska 15, supra note 79, at 150-52. The Sifre's author identified a number of different kinds of plants that fall under the obligation to tithe, such as pulse, garlic, pepperwort and field rocket. Id. 
grows from the earth." ${ }^{92}$ Thus, it includes all produce, and not just that explicitly mentioned in Deuteronomy. ${ }^{83}$ This definition excludes that which grows wild (i.e., is not cultivated) or is inedible, immediately raising two interesting definitional questions and opportunities for evasion. The first question is what it means to be "wild." The Talmud specifies that one who abandons his produce but later reclaims it is exempt from tithes (but not the other obligations, such as pe'ah and leket),${ }^{84}$ presumably on the theory that such produce becomes "wild." 85 The ability to abandon and reclaim produce would allow people to avoid the tithe quite easily. As a result, the rabbis enacted a series of rules to make it more difficult to avoid the tithe using this technique. These rules included the required presence of three people (any of whom might claim the abandoned produce in the presence of the other two who would act as witnesses) and a waiting period of three days, so as to allow time for others to claim the produce. ${ }^{86}$

The second question is what it means to be "edible." Flax is obviously an inedible crop. However, other crops might present difficulties in classification. For instance, anyone having attended a Grateful Dead concert (and quite a few who have not) can testify that cannabis has been baked into goods and consumed on occasion, raising the question of whether cannabis is subject to tithe. This is not to say that cannabis was a crop routinely grown in Israel, though some have sought to link the word "cannabis" to the Torah and have argued that cannabis was in use during Biblical times. ${ }^{87}$ Rather, it is to show that even seemingly simple and non-controversial distinctions can be problematic.

82. The Mishnah, Maaserot 1:1.

83. Later commentators struggled with the question of whether the obligation to tithe set forth in the Mishnah is a Torah obligation, or whether it is more properly considered a rabbinic obligation. Based on the explicit mention of grain, wine and oil, some concluded that the obligation to tithe grain, wine and oil is a Torah obligation, while the obligation to tithe other types of produce represents a rabbinic obligation. See, e.g., Rashi, Tosafot, Bava Metzia 88b. In contrast, Rambam concluded that the obligation to tithe all edible produce other than vegetables was a Torah obligation, while vegetables were a rabbinic obligation. Rambam, Mishneh Torah, Zeraim, Terumos 2:1, 2:6.

84. Pe'ah is the practice of leaving the corners of one's fields unharvested, and leket is the practice of leaving the fallen produce where it lies. Both practices are designed to ensure that the poor have sufficient food. See supra text accompanying notes 60-61.

85. Bablyonian Talmud, Bava Kama 28a, 94a.

86. Bablyonian Talmud, Nedarim 43a-45a; The Tosefta, Maaserot 3:11.

87. See, e.g., WiKIPEDIA Cannabis, http://en.wikipedia.org/wiki/Cannabis (last visited Oct. 23, 2006) (suggesting the Torah as a possible source for the word "cannabis"); WIKIPEDIA Religious Use of Cannabis, http://en.wikipedia.org/wiki/Spiritual_use_of_cannabis (last visited Oct. 23, 2006) (arguing that cannabis was in use during Biblical times). Wikipedia is an online encyclopedia that anyone may edit, and therefore of somewhat questionable accuracy. 
Assuming that one can identify a given crop as edible, it does not automatically follow that the crop is always subject to tithes. Some crops are edible from the moment they begin to grow (e.g., leafy green vegetables), while others are only edible late in their development (e.g., most fruits), while still others may start out edible and then become inedible as they mature (e.g., plants that have gone to seed). In recognition of this, the Mishnah and commentaries thereon contain a series of rules applicable to the different types of food crops. For instance, if produce is edible at the outset of its growth cycle and remains so until harvested, it is subject to tithe throughout its growth cycle, even though a farmer allows it to grow until late in the season before harvesting it. ${ }^{88}$ However, anything that is inedible during the early stages of development is not subject to tithe until it becomes edible. ${ }^{89}$ Produce that is edible during its early stage of development, but inedible at a later stage, is not subject to tithe once it becomes inedible..$^{90}$

These refinements beg the question of when different types of produce are edible, and the halacha does not disappoint. Rather, it provides a series of rules for, among other things, figs, grapes, sumac, mulberry, pomegranates, dates, peaches, walnuts and almonds, indicating when each is considered edible, and therefore subject to tithe. ${ }^{91}$ Grapes become subject to the law of tithes when their seeds become visible, ${ }^{92}$ sumac and mulberry when they have become red, pomegranates when they have become soft, etc. ${ }^{93}$ Generally speaking, as reflected in the above examples, the rules focus on when the fruit ripens. However, for some produce, such as walnuts, almonds and olives, different rules seem to apply, such as when the fruit is first formed (walnuts) and when the fruit can produce an economically valuable amount of oil (olives). ${ }^{94}$

The question of what constitutes a "field" also posed significant problems, insofar as the boundary between fields, the wild, and human residences was at times difficult to discern. According to Rambam, the Torah did not subject a tree planted inside a house to the laws of tithes because it was not in a field, even though certain rabbis instructed that such trees were

\footnotetext{
88. The Mishnah, Maaserot 1:1.

89. Id.

90. The Tosefta, Maaserot 1:1.

91. The Mishnah, Maaserot 1:2-3

92. Indeed, this statement is not sufficient to cover the situation where one grape in a bunch has visible seeds, but others do not. The Tosefta concludes that if seeds are visible in only one grape in a bunch, the entire bunch is subject to the law of tithes. The Tosefta, Maaserot 1:1.

93. The Mishnah, Maaserot 1:2-3.

94. See, e.g., The Mishnah, Maaserot 1:2-3; The Mishnah, Shebiit 4:9.
} 
subject to tithe. ${ }^{95}$ Onions, which have a tendency to sprout once harvested, also created problems. As set forth in the Mishnah, if an onion sprouts in the dirt of an attic, the onions will be deemed to be planted in fields (and therefore subject to tithes) if the attic is open to the sky. ${ }^{96}$ However, if the attic is enclosed, the onions will be deemed to be not planted in a field, and therefore free of the obligation to tithe. ${ }^{97}$

The last question is: What constitutes Israel? Rambam explained that it includes any land conquered by a king of Israel or a prophet with the consent of a majority of the people. ${ }^{98}$ It excludes any land conquered by an individual Israelite family or tribe, even if it is part of the land promised to Abraham. ${ }^{99}$ Thus, the "promised land" is not necessarily co-extensive with Israel, at least for purposes of agricultural tithing. With regard to Syria, Rambam explained that this land lost its status as "outside of Israel" when King David conquered it. However, it does not qualify as land within Israel because the conquest occurred before King David conquered all the kingdoms within Canaan. ${ }^{100}$ Accordingly, the Torah does not impose an obligation to tithe on produce grown in Syria. Nonetheless, rabbinic law imposes such an obligation. ${ }^{101}$

As if to demonstrate that no detail or scenario is too small to consider, the Mishnah contains rules on how to treat the fruit from a tree rooted in Israel but with a fruit-bearing bough extending beyond and, conversely, a tree rooted abroad, but with a fruit-bearing bough extending into Israel. ${ }^{102}$ The Mishnah concludes that the location of the roots governs. ${ }^{103}$ If the roots stand within Israel, the produce can truly be said to be from the fields of Israel, and therefore subject to tithes. Conversely, if the roots lie outside of Israel, the fruit is a product of that land and not subject to tithes, even though the fruit itself grows within Israel. ${ }^{104}$

95. Rambam, Mishneh Torah, Zaraim, Maaserot 1:10.

96. The Mishnah, Maaserot $5: 2$. That said, according to the Tosefta, there is no penalty if one does not tithe from onions grown in an attic with a collapsed roof. The ToseftA, Maaserot 3:9.

97. The Mishnah, Maaserot 5:2.

98. Rambam, Mishneh Torah, Zaraim, Tenufah 1:2.

99. Id.

100. Id. at $1: 3$.

101. Id. at $1: 4$

102. The Mishnah, Maaserot 3:10.

103. $I d$.

104. The Tosefta takes this question to the logical next step by addressing what to do with a tree that physically grows on the border and has roots both within and outside Israel. The commentary reveals a dispute, where one rabbi takes the position that the entire tree should be treated as existing within Israel, while another takes the position that the fruit from the half of the tree rooted in Israel is subject to the laws of tithes, and fruit from the other half is not. The Tosefta, Masserot 2:22. 
The question of what constitutes Israel is analogous to the source questions that arise in the U.S. taxation of non-resident aliens and foreign corporations, ${ }^{105}$ which are only taxed on their U.S.-sourced income. ${ }^{106}$ When income is limited to produce, those questions focus primarily on the definition of territory, as described above. For business transactions, which can transcend national boundaries, complexity develops. Nonetheless, questions of territory remain. For instance, while $\S 861$ of the Internal Revenue Code does not expound on the traditional boundaries of the U.S., it does distinguish between U.S. territory and that of its possessions. ${ }^{107}$ As discussed below in Part III(B)(1)(c), questions of source may contribute significant complexity in any international tax system.

\section{b. The Realization Requirement}

Determining what produce is covered by the law and when in the growing cycle the produce is subject to tithe does not end the inquiry. As with the U.S. federal income tax system, the fact that something is termed income is a necessary, but not sufficient, condition of taxation. A realization event must also occur. In Eisner v. Macomber, the U.S. Supreme Court went to great lengths to liken income to the fruit of a tree that could be taxed only after it had been separated from the tree, i.e., realized. ${ }^{108}$ While the Court has since backed away from the position that realization is inherent in the definition of

105. Source questions also arise in state taxation. Most states seek to impose taxes on income earned by non-residents that is derived from sources within their boundaries. See, e.g., CAL. Rev. \& TAx. Code $\S 17041$ (b), (d) (West 2005); McCulloch v. Franchise Tax Bd., 390 P.2d 412, 420 n.10 (Cal. 1964) (noting states can impose tax on the income of their residents, wherever it is earned, and on the income of nonresidents to the extent such income is derived from sources within the state). Thus, it is necessary to define who is a resident and what income can properly be deemed derived from the state. See, e.g., CAL. REV. \& TAX. CoDE $\S \S 17014-16$. See also $\S \S 17017-18$ (defining the terms "United States" and "State").

106. I.R.C. $\S \S 871,881(2000)$.

107. See, e.g., $\S 861(\mathrm{c})(3)(\mathrm{C})$ (compensation) and $\S 862(\mathrm{a})(8)$ (property).

108. Eisner v. Macomber, 252 U.S. 189, 206 (1920) ("The fundamental relation of 'capital' to 'income' has been much discussed by economists, the former being likened to the tree or the land, the latter to the fruit or the crop; the former depicted as a reservoir supplied from springs, the latter as the outlet stream, to be measured by its flow during a period of time."). 
income, ${ }^{109}$ the requirement and the metaphor remain mainstays of U.S. taxation. ${ }^{110}$

In the context of agricultural tithing, the notion of the fruit and the tree takes on more than metaphorical meaning. While the halacha does not use the phrase "realization," Jewish farmers were not required to tithe on produce they had not harvested. Indeed, the tithe did not have to be removed until the farmer had taken sufficient steps to demonstrate his control over the produce in question. ${ }^{111}$ This realization requirement takes on special significance in Jewish law because one may not consume food as part of a meal until the tithe has been removed. ${ }^{112}$ Thus, it was important to know exactly when the tithe had to be removed lest one inadvertently eat forbidden fruit.

The Mishnah devotes significant attention to the question of when during the harvest process tithes must be removed, breaking the question down by the different types of produce and the different processing the produce undergoes. ${ }^{113}$ Generally speaking, tithes must be removed when the farmer has harvested the produce and taken steps to demonstrate control over it, ${ }^{114}$ whether by processing the food or storing it at home. ${ }^{115}$ Thus, the moment at

109. See, e.g., Cottage Sav. Ass'n v. Comm'r, 499 U.S. 554, 559 (1991) (stating in dicta that "the concept of realization is "founded on administrative convenience"'). Not all scholars agree with the assessment in Cottage Savings. See Henry Ordower, Revisiting Realization: Accretion Taxation, the Constitution, Macomber, and Mark to Market, 13 VA. Tax Rev. 1 (1993). See also Marjorie Kornhauser, The Constitutional Meaning of Income and the Income Taxation of Gifts, 25 ConN. L. Rev. 1 (1992) (exploring whether the Constitutional definition of income necessarily included a realization requirement).

110. Assignment of income is another area where the fruit and the tree metaphor is used. See, e.g., Lucas v. Earl, 281 U.S. 111 (1930) (describing "the arrangement by which the fruits are attributed to a different tree from that on which they grew"); Joseph P. McGrath, Coupon Stripping Under Section 1286: Trees, Fruits, and Felines, 38 Tax Law. 267 (1985); Charles S. Lyon \& James S. Eustice, Assignment of Income: Fruit and Tree as Irrigated by the P.G. Lake Case, 17 TAX L. Rev. 293 (1962).

111. See Rambam, Mishneh Torah, Zaraim, Maaserot 2:1; The Mishnah, Maaserot 2:1-2; Jaffee, supra note 37 , at 1 .

112. This would be akin to a prohibition on using money until a tax had actually been paid on it. Interestingly, one may eat produce during the harvest, so long as the consumption is deemed to be a snack, as opposed to a meal, raising the difficult (and complex) question of how one distinguishes between the two. See The Mishnah, Maaserot 2:1-2 (rejecting a bright-line test in favor of one based on intent).

113. Thus, tithes must be removed from cucumbers and gourds when their fuzz is removed or when they are stacked, if the fuzz is not removed. For green vegetables, tithes must be separated when the vegetables are tied together. The Mishnah, Maaserot 1:5.

114. The Mishnah, Maaserot 2:1-2; The Tosefta, Maaserot 2.

115. Indeed, even the question of what qualifies as a home is subject to further refinement. For instance, courtyards that are confined and effectively closed to the public are deemed part of the house for purposes of determining when tithes are due, while courtyards that are more in the nature of public spaces are not considered part of the home. The Mishnah, Maaserot 3:5. Indeed, rules exist regarding how to treat the fruit from a tree that grows in a courtyard, but which has one fruit-bearing limb that extends beyond the courtyard. The Mishnah, Maaserot 3:10. 
which tithes must be removed depends to some degree on the farmer's intent and acts, much as the moment income is realized for federal income tax purposes is within the control of the taxpayer.

The realization requirement also provided significant opportunities to avoid the tithe altogether. ${ }^{116}$ For instance, to the extent that farmers intended to feed grain to animals, they could conceal the grain in the chaff and then feed the chaff directly to the animals, without triggering a need to tithe. ${ }^{117}$ Another way to avoid the tithe was to bring the produce into the house other than through the front door. The obligation to tithe is imposed when produce is brought into the house in a normal way. ${ }^{118}$ Thus, enterprising persons seeking to avoid the tithe developed ways to bring produce into the house through unorthodox means, thus avoiding the literal stricture of the law. ${ }^{119}$ As discussed below, ${ }^{120}$ the ability to avoid the tithe in these ways is a source of significant complexity.

\section{c. In-Kind Income Measurement}

In the U.S., the dollar is the unit of measurement both for determining the amount of income and the amount of tax. Thus, where the tax rate is 10 percent, a person who receives $\$ 100$ worth of a commodity as income owes $\$ 10$ in tax. Moreover, because monetary income is largely fungible, ${ }^{121}$ he may pay his $\$ 10$ tax using dollars from any source. ${ }^{122}$ As a result, determining the amount of the tax and identifying the source of the payment is fairly straightforward.

Because agricultural tithing treats commodities as income and requires that tithes be separated in-kind, two interesting issues arise that are not present in federal income taxation. The first is what unit one should use to measure

116. For a discussion of how farmers could evade the tithe and Jewish attitudes regarding such evasion, see Shmuel Shilo, Evasion of the Law in the Talmud, translated and reprinted in STUDIES IN JeWish LAW, at 171.

117. See, e.g., Babylonian Talmud, Berakoth 31a.

118. See The Mishnah, Maaserot 3, 5, 6, \& 7 (describing the different types of structures that qualify as a home for tithing purposes).

119. See Babylonian Talmud, Berakoth 35b.

120. See text accompanying notes $162-66$.

121. Certain rules, such as those in I.R.C. $\S 469$ (2000), limit the fungibility of income and deductions for purposes of calculating the amount of tax due. Such rules reflect an effort to prevent the improper sheltering of income, as opposed to physical differences in the different types of income or expenses.

122. In some limited cases, such as with pensions and individual retirement accounts, taxpayers are restricted in their use of specific funds. However, this is the exception, and not the rule. 
income and determine the amount of the tithe. The second is whether income is fungible, thus allowing a farmer to satisfy the tithing obligation by taking the entire tithe out of one crop, while keeping for himself all the produce of another. These issues create complexity not present in modern tax systems.

Where income is a commodity that may be measured in a variety of ways, the amount of the tithe may differ significantly depending on the unit of measurement used. For instance, if a farmer has 100 pumpkins weighing a total of 100 pounds, he might owe 10 pumpkins or 10 pounds worth of pumpkins, depending on how the produce is measured. If the latter, he might be able to satisfy his obligation with one big pumpkin. If the former, he will have to decide which 10 pumpkins to give away, and he may give away significantly more or less than 10 percent of his food when measured by weight. According to Rambam, one should not estimate. ${ }^{123}$ Rather, the Mishnah instructs that one who determines the tithe by counting is worthy, one who does so by measurement is better, while one who does so by weight is the most worthy. ${ }^{124}$ This preferred rule seems designed to ensure that, where the size and weight of produce is variable, sufficient food is set aside for those who receive the tithes, reflecting the underlying purpose for the tithe. ${ }^{125}$

An ancillary issue that arises with in-kind income is the quality of the income used to satisfy the tax obligation. A farmer with 100 apples might be tempted to give ten pounds of shriveled apples as his tithe, as opposed to 10 pounds of his best or randomly chosen apples. Were such behavior allowed, the tithe recipients would likely suffer. Thus, the Torah requires that one tithe from choice produce. ${ }^{126}$

The second issue that arises is whether a farmer with many crops may satisfy the 10 percent obligation by tithing from one crop alone, or whether the obligation is crop, or even field, specific. For instance, if a farmer grows

123. Rambam, Mishneh Torah, Zaraim, Maaserot 1:14.

124. The Mishnah, Terumos 4:6.

125. When one tithes based on a count, an additional issue arises. Counting takes time. One solution is to determine how much produce a given container holds and then simply remove $1 / 10$ th of that amount every time the container is filled. The Mishnah permits such a technique. However, the size of mature produce changes over the growing season. Accordingly, the Mishnah requires that one determine how much the container holds three times during the growing season. Thus, if the container holds 100 apples at the first measurement, one may remove 10 apples until the next measurement. If the container holds 110 apples at the second measurement, one must remove 11 apples until the next measurement. If the container holds 120 apples at the last measurement, one must remove 12 apples until the harvest is complete. THE MishnaH, Terumos 4:6.

126. Numbers 18:30; Rambam, Mishneh Torah, Zaraim, Maaserot 1:13. 
grapes and grain and harvests 100 pounds of each, does he owe 10 pounds each of grain and grapes, or can he tithe 20 pounds of one or the other? According to Rambam, crops are not fungible. Rather a farmer owes 10 percent of each crop. ${ }^{127}$ However, if a farmer grows the same crop in two distant fields, he need not tithe from each field, but rather from the total. ${ }^{128}$ In contrast, the $p e$ 'ah obligation, which requires that one leave the corners of the field unharvested for the poor, is field specific. ${ }^{129}$ Thus, if one has ten fields, one cannot satisfy the $p e$ 'ah obligation by fully harvesting nine fields and leaving one untouched.

While the rules regarding fungibility are based on the underlying language imposing the obligations, ${ }^{130}$ they also reflect the underlying purpose motivating the obligations. With regard to crops, if the farmer were allowed to satisfy his tithing obligation from one crop, the enterprising farmer could plant one low-value crop to satisfy his tithing obligation and keep the rest for his own uses. Moreover, those depending on the tithes, i.e., the Levites and the poor, could end up with nothing but alfalfa one year and parsley the next. Thus, this rule serves the purpose of ensuring that tithes contain an even distribution of what is produced. The rule requiring that one tithe from choice produce ensures that the tithe is indeed edible. ${ }^{131}$ Similarly, if one were allowed to satisfy the $p e$ 'ah obligation from just one field, the distribution and availability of food would be severely limited, as farmers might be tempted to plant one field at the top of a distant mountain and leave it unharvested and available to the poor. Under the existing rule, farmers have no incentive to engage in such games, and food will be available in every field. In contrast, no one is harmed if a farmer aggregates a specific crop before tithing.

\section{Netting}

Determining what is included in gross income is merely the first step in arriving at taxable or tithable income. The next step requires that one determine whether any amounts may be deducted from gross income. Federal income taxation permits the deduction of expenses, while agricultural tithing does not. Yet, despite this difference, the two systems may be more similar in this regard than meets the eye.

127. Rambam, Mishneh ToRah, Zeraim, Maaserot 1:6.

128. Id.

129. See Leviticus 19:9.

130. See generally Deuteronomy 14:22; Leviticus 19:9.

131. Numbers 18:30. 
For purposes of federal income taxation, while deductions are "a matter of legislative grace," 132 they have been allowed from the very beginning. Insofar as the underlying goal is to tax accessions to wealth, the ability to net expenses against gross income is a fundamental part of determining taxable income. This is especially true in a complex economy, where the costs of different kinds of businesses differ significantly, and taxing gross income would lead to widely differential taxation of profits and even taxation of those who lost money. Thus, the issue in federal income taxation quickly devolves into which expenses are deductible and under what conditions. Generally speaking, only "ordinary and necessary" expenses that the taxpayer incurs on his own behalf are deductible. ${ }^{133}$

In contrast, agricultural tithing precludes deductions. ${ }^{134}$ Nonetheless, a number of exclusions exist, such that tithes are not owed on every apple or grain of wheat that grows in the field. For instance, amounts left in the field as part of the pe'ah obligation are excluded from income. ${ }^{135}$ Terumah $^{136}$ is also removed before the tithe is determined. And the second tithe is determined net of the first tithe. If part of a harvest is stolen or destroyed, no tithe is owed on those amounts. ${ }^{137}$ In each of these examples, what might otherwise have been counted as income is excluded, and the tithe is imposed on what is left. The same result could have been achieved by including these items in income and then giving a deduction for produce left in the field or offered as terumah or as the first tithe.

132. INDOPCO, Inc. v. Comm'r, 503 U.S. 79, 84 (1992) (quoting Interstate Transit Lines v. Comm'r, 319 U.S. 590, 593 (1943)).

133. I.R.C. § 162 (2000); Williams v. Comm'r, 19 T.C.M. (CCH) 106, 111 (1960).

134. For instance, Rabbi Bachrach (1638-1701) wrote:

But as scripture commanded us to separate terumah and maaser without any deductions, we are driven to the conclusion that it is a scriptural decree that no expenses may be deducted. The Almighty has obligated us to give terumah to the Cohen and maaser to the Levi from all new produce which the field has brought forth, and the expenses are to be met personally from what remains of the crop after separation of terumah and maaser.

MAASER KeSAF IM, supra note 79, at 55-56 (emphasis added).

135. See text accompanying note 60 .

136. This is the offering of a small amount of produce that must be made to the priests, who consume the offering when ritually pure. See supra note 64.

137. Babylonian Talmud, Gittin 44a; Babylonian Talmud, Hullin 131a. These passages refer to a baraisa (written authority from the time of the Mishnah) that addresses what happens if crops are seized by a king in satisfaction of a debt. As is the case in federal income taxation, such a transaction is deemed tantamount to a sale, and the farmer is still liable for tithes on such produce because selling produce does not excuse one from the obligation to tithe on that produce. However, when the king seizes produce without a claim of debt, such produce is excluded from income. In the U.S., this would lead to a casualty loss deduction, which functionally excludes the lost produce from income. See I.R.C. § 165 (2000). 
The rule against deductions appears to be based in the language imposing the obligation to tithe, which makes no allowance for any deductions. That said, several additional reasons for such a rule present themselves. First, it is not clear as a practical matter how one would net costs against in-kind payments. This problem is compounded where such costs are in-kind and not readily determined. Second, it is not clear that the costs will differ significantly from farmer to farmer. In such a case, equity concerns do not require imposing the tax on net income. Rabbi David Oppenheim (1664-1736) articulated a third justification for not allowing netting, one that highlights how the religious context can influence income definition. In his effort to distinguish maaser kesafim (i.e., non-agricultural tithing, where netting is allowed) from agricultural tithing he wrote:

But we must conclude that there is no comparison between maaser kesafim for business deals and agricultural maaser for produce of the earth. In the latter case we have a special biblical decree since the whole matter of growth of agricultural produce is a miracle of nature even when the seed which is planted is not itself consumed, and more especially when the seed is consumed, which represents the main Torah obligation.... However, business dealing is a practice among people of the world with no reference to anything miraculous. . . ${ }^{138}$

This appeal to the divine foreshadows to some degree the federal income tax requirement that expenses be "ordinary and necessary" and incurred on one's own behalf. Underlying the notion of "ordinary and necessary" is the perception that the expense incurred is in fact directly connected to the generation of income. Indeed, an expense is deductible because it leads to the generation of income. Where no connection exists between the expense and the income, no deduction is allowed. While a farmer's expenses are ordinary and necessary in the common understanding of those words and are deductible under the federal income tax, the passage quoted above gives God the credit for generating agricultural income. Accordingly, it would be improper to allow a deduction for any human-incurred expenses.

\section{Accounting Periods and Timing}

The third issue that arises in both federal income taxation and tithing is timing. This includes the subsidiary questions of determining the appropriate accounting period, i.e., the period over which income is to be measured, and whether a specific item of income or deduction (if allowed) falls within a 
given period. ${ }^{139}$ The Torah expressly establishes a one-year accounting period for agricultural tithing. ${ }^{140}$

Determining the year to which produce belonged was critical because tithes were to be used for different purposes in different years. Moreover, using produce from one year to satisfy the tithing obligation of another was not permitted. ${ }^{141}$ The Tosefta states a general rule that crops belong to the year in which they are harvested. ${ }^{142}$ Thus, Rambam concluded that vegetables belong to the year in which they are picked. ${ }^{143}$ However, a different rule applies for fruit. As set forth in the Mishnah, the great scholarly houses of Hillel and Shammai agreed that, if fruit reached maturity during year 1, it belonged to year 1 , even if not picked until the following year. ${ }^{144}$ They disagreed regarding crops whose fruit had set in year 1, but did not ripen until the following year. Regardless of which house was correct, it is clear that the picking of the fruit, i.e., the realization event, did not always determine the year to which the income belonged.

139. To the extent that the realization requirement is separate from the question of what can be considered income, it properly belongs under timing, as it determines when an item of income becomes subject to tax. In addition, it can be viewed as an example of transactional, as opposed to annual, accounting. Myron C. Grauer, The Supreme Court's Approach to Annual and Transactional Accounting for Income Taxes: A Common Law Malfunction in a Statutory System?, 21 GA. L. Rev. 329, 393-97 (1986).

140. Deuteronomy 14:22 (requiring tithing "year by year"). Unlike the Gregorian calendar, which is based on a solar year, the Jewish calendar is based on a lunar year. In fact, while the period is one year, agricultural tithing actually had two different one-year periods. The agricultural year with regard to the produce of trees began on Tu bshvat (meaning the 15th of the month of Shvat), which generally falls in January or February. With regard to vegetables and other produce, the agricultural year began on the first of Tishri, commonly known as Rosh Hashanah, which generally falls in September or October. RAmBAm, Mishnem Torah, Zeraim, Maaser Sheni Neta Revai 1:2. These different growing periods reflect the different growing patterns for trees and other produce. While Rosh Hashanah falls in the middle of the traditional American harvest time and could create significant timing issues here, in Israel, the planting season begins shortly after Sukkot, which is approximately a month after Rosh Hashanah. Thus, most produce would clearly fall within one year or another. See NATHAN Bushwick, Understanding the Jewish CALENDAR (1989), for an in-depth discussion of how the Jewish calendar works.

141. See, e.g., MAASER KesAF IM, supra note 79, at 61-62 (Rabbi Yaakov Reicher (c. 1670-1733) relied on the notion that it was improper to use crops from one year to satisfy the tithe of another year to conclude that losses from one transaction could not be used to offset gains from another.).

142. Thus, for crops planted in year 2 of the seven-year cycle, but not harvested until year 3 , the farmer must separate maaser ani, the tithe for the poor, as opposed to maaser sheni, the tithe the farmer was to consume in Jerusalem. The Tosefta, Maaserot 1:5a.

143. Rambam, Mishneh ToRah, Zeraim, Maaser Sheni Neta Revai 1:4.

144. The houses disagreed regarding the treatment of fruit that had blossomed, but not ripened before the new year, with Hillel holding that the fruit belonged to the first year, and Shammai holding that the fruit belonged to the new year. The Tosefta, Maaserot 1:5a. 


\section{TIthing AND TAX REForm}

The example of agricultural tithing allows us to observe the effects of the elimination of the features that are perceived to be major sources of complexity from an income tax system, such as a progressive rate structure or the capital gains tax preference. In addition, because agricultural tithing can also be described as an income-based consumption tax, exploration of whether this form of taxation will likely deliver the simplicity gains promised on behalf of such systems is possible.

It should be evident after reading the foregoing description and analysis that even a "simple" income-based tax can be quite complex. However, one need not rely solely on intuition. Using the tools developed in the tax complexity literature, identification of the different types of complexity present in agricultural tithing is possible. Such analysis yields two important lessons regarding tax complexity and simplification efforts. First, even farreaching reform of the current income tax is unlikely to result in a tax system that most would consider simple. Second, popular claims, such as those made by Steve Forbes, that an income-based consumption tax will be simple are overstated. While such tax systems may eliminate some of the complexity inherent in a true income tax, to the extent that the proxy of income is used to measure consumption, the same complicating issues of income measurement will arise.

While agricultural tithing admittedly has income measurement complications not present in a modern income tax, such as those that arise from in-kind transactions it also lacks many of the factors, such as cutting edge financial transactions and sophisticated international tax issues that add significant complexity to any modern tax. These modern issues more than compensate for the lack of in-kind issues. As should be clear from the review of agricultural tithing, income measurement issues alone are sufficiently complex to defeat claims that either a stripped down income tax or an incomebased consumption taxes will deliver us to the "Promised Land of taxation."145

\section{A. Reforming the Current Income Tax}

Returning to the opening point of the article, reforming the income tax to eliminate complexity has been a priority almost since the tax was enacted. ${ }^{146}$

145. Johnson, supra note 3, at 578.

146. See supra note 1. 
The scholarship on this issue includes both theoretical efforts to identify the causes and nature of tax complexity and efforts to suggest specific types of practical reforms, such as creating a uniform definition of "child."147 In addition, scholars across the political spectrum routinely cite complexity as a justification for their favored reform. Thus, critics of progressivity have argued that graduated tax rates are a major source of tax complexity. ${ }^{148}$ Others have claimed that the capital gains tax preference is a major source of tax complexity and should therefore be eliminated. ${ }^{149}$ Still others assert that the passive loss rules generate the greatest complexity. ${ }^{150}$

Although several scholars have concluded that complexity is inevitable, ${ }^{151}$ and at least one has declared that, like greed, complexity is good, ${ }^{152}$ most seem to think that, if only we could identify and eliminate the sources of complexity, we could design a simple income tax. The example presented by agricultural tithing, which eschews progressivity, is devoid of a capital gains tax preference, omits any passive loss limitations, and indeed omits all deductions, suggests that a significant level of complexity is simply unavoidable in an income tax, regardless of the design features one chooses.

147. See Working Families Tax Relief Act of 2004, Pub. L. No. 108-311, 118 Stat. 1166, (making changes to I.R.C. § 152).

148. See, e.g., Blum \& Kalven, supra note 4. Professors Blum and Kalven assert that progressivity "produces a tax law of almost impenetrable complexity. It invites a distorting attention to the tax aspects of any economic transaction. It affords an excessive stimulus to tax avoidance with perhaps incalculable consequences for taxpayer morale and the general respect for the law." Id. at 434-35. See also Charles Galvin \& Boris Bittker, The Income Tax: How Progressive Should It Be? 16 (1969) ("[F]or the principle of progressivity we pay a high price in the extraordinary complexity of our present system.").

149. See, e.g., Office of the Sec'y, Dep't of the Treasury, Tax Reform for Fairness, Simplicity, and Economic Growth: The Treasury Department Report to the President at 180-81 (1984) (describing the capital gains preference as a "source of substantial complexity"); Daniel L. Simmons, The Tax Reform Act of 1986: An Overview, 1987 BYU L. Rev. 151, 179 ("Not only did [the capital gains] preference provide a major advantage to a form of realized gain, it was perhaps the greatest single contributor to complexity in the Internal Revenue Code. Elimination of the capital gains preference may be one of the most significant features of the 1986 Act.").

150. See, e.g., Mona L. Hymel, Tax Policy and the Passive Loss Rules: Is Anybody Listening?, 40 Ariz. L. Rev. 615, 642 (1998).

151. See, e.g., John F. Witte, The Politics and Development of the Federal Income Tax 196-98, 370 (1985) (arguing that simplicity must be traded away for the important goals of equity and efficiency); R. George Wright, The Illusion of Simplicity: An Explanation of Why the Law Can't Just Be Less Complex, 27 Fla. St. U. L. REv. 715, $743-44$ (2000) (concluding that complexity cannot be avoided).

152. Samuel A. Donaldson, The Easy Case Against Tax Simplification, 22 VA. TAX ReV. 645, 650-52 (2003) (arguing that (1) "the forces comprising tax complexity are either inevitable or net beneficial," (2) "the alleged harms of tax complexity are either unproven or overstated," (3) proposed simplifications either increase complexity or overcorrect for perceived harms, and (4) "simplicity is an overrated policy objective"). 
In examining the possibility that reforming the income tax would produce a meaningful reduction in complexity, consideration of the laws of agricultural tithing in light of the theoretical framework set forth by Edward J. McCaffery is helpful. ${ }^{153}$ Professor McCaffery set out to refute the notion that one must trade simplicity for other goals, such as equity and efficiency. In the process, he provided a cogent description of the different types of complexity and their causes. He described complexity as consisting of three main types: (1) technical, i.e., the difficulty of understanding the meaning of a tax law; (2) structural, i.e., the difficulty of applying the rules to specific transactions and the ability to structure transactions in different ways to obtain or avoid certain tax results; and (3) compliance, i.e., the difficulty associated with the procedural burdens of record keeping. ${ }^{154}$

Professor McCaffery also broke down the sources of complexity into two categories: static and dynamic. ${ }^{155}$ Static sources arise from initial decisions regarding the nature and structure of the tax. Dynamic sources are those that arise as taxpayers respond to the tax laws, causing further refinement and changes to the laws. With regard to static sources, some complexity is unavoidable, such as questions of measurement and timing. Others are avoidable, such as decisions to use the tax system to achieve goals external to income measurement and taxation. ${ }^{156}$ Dynamic complexity appears unavoidable. ${ }^{157}$

The Jewish experience with tithing suggests that even after the most drastic of reforms, significant complexity is unavoidable. In tithing, much of the static sources of complexity are avoided. Agricultural tithing allows for no deductions, thus eliminating the need for complicated rules for determining which expenditures should be allowed and which should not. Agricultural tithing also lacks progressive rates and the preferential treatment of different types of income, long thought to be major sources of complexity. Thus, the incentives to assign income to others or convert it from one type of income to another are eliminated, as are the rules necessary to prevent such behavior. Finally, agricultural tithing lacks rules designed to accomplish non-tax objectives. Given these design features, one might expect agricultural tithing

153. See McCaffrey, supra note 2.

154. Id. at 1271-72. See also Johnson, supra note 3, at 582 (Professor Johnson uses the terms "Detail," "Outcome" and "Forms" complexity to describe the same basic types of complexity.).

155. McCaffrey, supra note 2, at 1273.

156. Id. at 1274 .

157. See id. at 1273-79. 
to be fairly simple. However, we still see significant technical, structural, and compliance complexity.

We see technical complexity in the definition of terms such as "Israel," "field" and "produce." 158 Each of these terms seems relatively straightforward. Nonetheless, they were not so obvious as to obviate the need for further elucidation. The tithing experience reveals that even when one reduces the notion of income down to something as simple as "the produce of the fields," volumes and volumes of legal authority can still be generated, creating significant technical complexity.

We see structural complexity in connection with the realization rules. ${ }^{159}$ Farmers could control the tax outcome of their behavior by carefully planning around the specific rules, which were construed quite strictly. For instance, farmers could conceal grain in hay and then feed that grain to their animals; fail to complete the harvest before bringing it into the home; or bring the produce into the house through the roof, as opposed to through the door. ${ }^{160}$ Another example of structural complexity appears in the rules regarding the abandonment of produce as a means to avoid the tithe. ${ }^{161}$ To prevent farmers from avoiding the tithe by formally abandoning their produce and then immediately reacquiring it, the rabbis created rules to limit such behavior. These rules made abandonment more difficult and ensured that the farmer was at some risk (however minimal) that someone else might claim his produce. ${ }^{162}$ Thus, not only did the possibility of avoiding the tithe by the above means lead to complicated behavior that would not otherwise have occurred, but it also led to the creation of additional rules imposed by the rabbis to prevent such avoidance. ${ }^{163}$

Finally, we see "compliance" complexity arising from the rule that produce from which no tithe had been separated is tevel, i.e., forbidden. Farmers must keep close track of which produce has been tithed; and once the tithes and other offerings have been separated, farmers must further keep track of those offerings until they are distributed or used as required. Thus, Rambam describes a lettering system for marking pots to identify their

158. See supra Part I(B)(1)(a).

159. See supra Part I(B)(1)(b).

160. For a discussion of these techniques, see Shilo, supra note 116, at 171. Such activities not only contribute to complexity, but they also lead to deadweight loss and inefficiency as people engage in activities they would otherwise eschew, simply to avoid the tax.

161. See supra text accompanying notes $84-86$.

162. See Babylonian Talmud, Nedarim 43a-45a; The Tosefta, Maaserot 3:11.

163. The example of abandonment also illustrates unavoidable dynamic complexity at work. The parties subject to the law and those making it are involved in an iterative process of action and reaction. 
contents. For instance, the letter " $\square$ " stands for maaser, the second tithe. The letter "T" stands for demai, doubtfully tithed produce. ${ }^{164}$ The letter "ט" stands for tevel, definitely untithed produce. The letter "ה" stands for terumah, the offering to the priests. ${ }^{165}$

This analysis is not meant to suggest that we should simply give up on efforts to simplify the current tax. Opportunity for tax simplification exists. Nonetheless, even assuming Congress would eliminate progressivity, capital gains preferences, and other sources of complexity, the remaining flat-rate income tax would nonetheless remain complex.

\section{B. Consumption Tax Complexity}

A number of scholars have seized on the intractable complexity of the income tax as justification for replacing the income tax entirely with some form of consumption tax. While once limited primarily to scholarly articles, ${ }^{166}$ the idea of "ripping the income tax out by its roots" 167 has gained significant political and popular traction. ${ }^{168}$ Thus, Steve Forbes twice ran for president largely on a "flat tax"169 platform and continues to this day to advocate for this type of tax reform. ${ }^{170}$ More recently, President George W. Bush's tax reform panel issued a recommendation that we either modify the income tax to make it function more like a consumption tax or replace the income tax with a consumption tax. ${ }^{171}$ While consumption tax proponents tout the purported

164. Special rules apply to produce when it is uncertain whether tithes have properly been removed. See, e.g., RAMBAm, MishneH TORAH, Zaraim, Maaserot 9:1.

165. Rambam, Mishneh Torah, Zaraim, Maaser Sheni Neta Revai 6:8.

166. See, e.g., HALl \& RabushKa, supra note 5, at 3; Andrews, supra note 5, at 1122; Isenbergh, supra note 5, at 286; McNulty, supra note 5, at 2103.

167. This phrase is attributed to Dick Armey, former Chairman of the House Ways and Means Committee, but it has been oft repeated. Howard Gleckman, Tax Reform Is Coming, Sure. But What Kind?, Bus. WK., June 12, 1995, at 87. For a listing of other uses of the phrase, see Johnson, supra note 3, at 574 n.6.

168. The Wall Street Journal routinely runs articles and op-ed pieces promoting either flat-rate income or consumption taxation. See, e.g., Alan J. Auerbach, Editorial, A Consumption Tax, Wall St. J., Aug. 25, 2005, at A8; Martin Feldstein, Op-Ed, Raising Taxes on Savings? Tell Joe It Ain't So!, WALL St. J., Dec. 8, 2005, at A16; Rhode Island Revelation, Op-Ed, Wall St. J., Feb. 10, 2006, at A18 (regarding a proposal for an optional flat rate income tax rate schedule).

169. The term "flat" tax generates a significant amount of confusion, especially when used in the popular press. On the one hand, it can mean a flat-rate income tax, where everyone pays the same rate on their income. On the other hand, it is often used to refer to the Hall-Rabushka proposal for a flat-rate, income-based consumption tax.

170. See Forbes, supra note 6, at 59; Steve Forbes, Editorial, One Simple Rate, Wall St. J., Aug. 21, 2005, at A12.

171. Report of the President's Advisory Panel on Feder al Tax Reform, Simple, Fair and 
efficiency of consumption taxation, they also focus sharply on the purported simplicity of such taxes, especially as compared to the current system. ${ }^{172}$

A consumption tax can take many forms, with the differences based largely on the different ways in which consumption is measured. ${ }^{173}$ The complexity of any such system will depend heavily on the form it takes. One possibility would be to retain the income tax but make changes, such as permitting immediate taxation of all expenditures, to make it function more like a consumption tax. ${ }^{174}$ More radical proposals include: the so-called "fair tax," which would operate as a national retail sales tax; ${ }^{175}$ the value added tax or VAT, similar to tax systems used in Europe and around the world; ${ }^{176}$ the cash-flow tax on individuals alone, ${ }^{177}$ or a two-tiered system, where individuals are taxed on their wages and businesses on their cashflows, ${ }^{178}$ such as the Hall-Rabushka Flat Tax (proposed by Robert Hall and Alvin Rabushka) ${ }^{179}$ and the X-Tax (proposed by David Bradford). ${ }^{180}$ The first two

Pro-Growth: Proposals to Fix America’s Fax System 59 (2006).

172. See Forbes, supra note 6, at 59. Moreover, the title of the President's panel report, supra note 175 , begins with the word "simple."

173. For a good discussion of the basics of consumption taxation, see Weisbach, Ironing out the Flat Tax, supra note 7, at 603-09.

174. Permitting the immediate expensing of expenditures is mathematically tantamount to exempting the income such expenditures generate from taxation. See E. Cary Brown, Business-Income Taxation and Investment Incentives, in Income, Employment and Public Policy: Essays in Honor of Alvin H. HANSEN 300, 301 (1948). Thus, such a change to the current income tax would accomplish the same thing as explicitly excluding such returns from the tax base.

The most common articulation of this approach is called "five easy pieces." See William G. Gale \& Peter R. Orszag, Bush Administration Tax Policy: Down Payment on Tax Reform?, 105 TAx Notes 879, 882 (2004). The other key elements of this plan include reducing marginal rates, integrating the corporate tax, increasing the ability to make deductible contributions to tax-free savings accounts, and moving towards a territorial tax, where export income and income earned abroad is not taxed in the U.S.

175. See Neal Boortz \& John Linder, The Fair Tax Book: Saying Goodbye to the Income TAX AND THE IRS 75-76 (2005); see also H.R. 25, 109th Cong., § 101(a) (1st Sess. 2005). The national sales tax and VAT proposals are probably the easiest to understand as measuring and taxing consumption, as they impose the tax at the time a product is consumed. The other proposals measure consumption less directly, and as will be discussed below, can often look like income taxes.

176. Professor Weisbach describes a VAT as "simply a complic ated method of collecting a retail sales tax." Weisbach, Ironing out the Flat Tax, supra note 7, at 610. Rather than collect the tax at the retail transaction level, the tax is collected at each stage of production. A tax collected in this manner is purportedly more difficult to avoid. $I d$. at 610 n.21. Numerous types of VATs exist. For a discussion of the differences, see $i d$.

177. See, e.g., David F. Bradford \& The U.S. Treasury Tax Policy Staff, Blueprints for BASIC TAX REFORM 101 (2d ed. 1984); Andrews, supra note 5, at 1122.

178. For a discussion of the impact and purpose of two-tiered consumption tax systems generally, see Weisbach, Does the X-Tax Mark the Spot?, supra note 7, at 202.

179. The Hall-Rabushka proposal, commonly referred to as the "Flat Tax," entails taxing individuals on their employment income (without allowing personal deductions) at a flat rate and taxing businesses 
proposals measure consumption on a transactional basis, i.e., at the time people consume. The latter two proposals measure consumption using a subset of what we traditionally consider to be income as a proxy for consumption. Although no one can say with certainty which form of consumption tax might be adopted, the leading contenders appear to be some form of income-based consumption tax, such as the X-Tax. ${ }^{181}$

In light of the recent surge in enthusiasm for consumption taxes generally and for income-based consumption taxes in particular, scholars have begun to consider the details of how such taxes would be implemented and to test the claims that real-world consumption taxes will be less complex than income taxes. Scholars have generally taken one of two approaches to the question of consumption tax complexity. The first approach is theoretical; it attempts to forecast complexity based on the expected presence of "root causes" of complexity. The second approach is practical; it focuses on the specific details of implementation. Both forms of scholarship are necessarily speculative insofar as no one knows what form of consumption tax might be adopted or what design features a given form might have. The Jewish experience with agricultural tithing reveals that significant complexity is unavoidable in any income-based consumption tax, regardless of the design features.

using a subtraction-method VAT. See The Freedom and Fairness Restoration Act of 1995, H.R. 2060, 104th Cong. §§ 101-02 (1995); HALL \& RABUSHKA, supra note 5, at 58, 61. This is the proposal that Steve Forbes championed during his two runs for president. See, e.g., ForBes, supra note 6. In fact, because Hall and Rabushka proposed exempting some basic level of wage income from taxation, the Flat Tax is arguably progressive. See Weisbach, Ironing out the Flat Tax, supra note 7, at 612. Others have characterized this structure as "degressive." See, e.g., Marjorie Kornhauser, Choosing a Rate Structure in the Face of Disagreement, 52 UCLA L. REv. 1697, 1731 (2005).

180. The X-Tax operates somewhat like the Hall-Rabushka Flat Tax, except that it incorporates "real" progressivity into the taxation of wages. President Bush's blue-ribbon Tax Reform Panel recommended two reform proposals. The first proposal recommended changes to the current income tax, while the second proposal recommended replacing the current income tax with a variation of Professor Bradford's X-Tax. See Simple, Fair and Pro-Growth, supra note 171.

181. For instance, in the Dunwoody Lecture delivered at the University of Florida in 2006, Professor George Yin, a former chairman of the Joint Committee on Taxation, argued that a national sales tax had little possibility of replacing the current income tax, noting that many of his arguments applied equally to VATs. See, e.g., George K. Yin, Is the Tax System Beyond Reform?, 58 Fla. L. REV. (forthcoming Dec. 2006). Professor Shaviro has speculated that, given the political climate in Washington, the most likely reform scenarios include either a stealth effort by Republicans alone to make the current income tax more like a consumption tax, or a joint effort to adopt some form of the X-Tax. See Shaviro, supra note 7, at 3. Indeed, as noted above, President Bush's tax reform panel suggested adopting an X-Tax style consumption tax. 


\section{The Theoretical Approach}

Deborah L. Paul approached the question of consumption tax complexity from a theoretical perspective. Like Professor McCaffery, ${ }^{182}$ she described three different types of complexity, based primarily on the cause. Her categories were: "complication," "intractability" and "incoherence."183 "Complication" refers to the sheer quantity of detailed authorities, i.e., the number of code sections and supporting regulations and other administrative pronouncements. ${ }^{184}$ "Intractability" refers to the difficulty of defining a given concept or applying a given provision. ${ }^{185}$ Thus, a law may consist of one simple sentence, like the basic antitrust statute or Deuteronomy 14:22, yet be complex because it is difficult to apply. "Incoherence" refers to the extent to which the purposes of the tax are expressed in, and served by, the system's legal authorities. ${ }^{186}$ Thus, provisions extraneous to the purpose of measuring income and inconsistent with the basic logic underlying the tax code, such as the exclusion of gain from the sale of a principle residence, can be viewed as incoherent and a source of complexity.

Ms. Paul contended that a tax system's complexity derives largely from two factors. First, she claimed that the level of "complication" is directly related to the amount of revenue at stake. ${ }^{187}$ That is, the greater the revenues at stake, the greater the cost of uncertainty, thus justifying the cost of generating an increased number of legal rulings, a significant cause of complexity. Second, she asserted that the "ability to pay" notion, which is reflected in a progressive rate structure, is "intractable." 188

Ms. Paul then used this theoretical construct to consider whether consumption taxation could deliver on its promised simplicity. Given that the amounts at stake would be large, she predicted that taxing authorities would create vast quantities of detailed legal rulings, thus leading to "complication." She also predicted that any consumption tax would incorporate some level of "intractable" progressivity. As a result, she concluded that consumption taxes were unlikely to deliver on the promise of simplicity. ${ }^{189}$

182. See supra text accompanying notes 156-60.

183. Deborah L. Paul, The Sources of Tax Complexity: How Much Simplicity Can Fundamental Tax Reform Achieve?, 76 N.C. L. REv. 151, 157 (1997).

184. Id. at 158 .

185. Id. at $159-60$.

186. Id. at 161 .

187. Id. at $163,169-74$.

188. Id. at 163-69.

189. See id. at 163-74. 
While this analysis seems correct, as far as it goes, the implication is that if one avoids a graduated rate schedule, and if the amounts with uncertain treatment under the law are small, it should be possible to design a consumption tax that delivers on the promise of simplicity. Agricultural tithing refutes that notion. First, as a flat-rate tax imposed on a limited subset of what might normally be considered income, tithing does not worry itself with "ability to pay." Thus, it lacks this key intractable concept to which Ms. Paul attributes significant complexity. Indeed, none of the terms that require definition, such as field, house, or Israel, seem to be terribly abstract or intractable. Rather, it appears that even the most common notions and the easiest ones to grasp are susceptible to hair-splitting and a proliferation of rules and definitions. Thus, while intractability may add to complexity, the lack thereof does not guarantee a simple tax system.

Second, the Jewish experience with tithing suggests that rules will multiply as a matter of course, regardless of the amount at stake. The number of trees growing directly on the border between Israel and Egypt is likely very small, as are the number of trees in Egypt with a limb extending into Israeli airspace. Nonetheless, such issues are routinely addressed in the halacha, adding to "complication," or the profusion of rules. While it is true that the normal cost-benefit analysis Ms. Paul proposes may not work in a situation where a violation of the rules might lead to eternal torment, those in doubt in these rare situations could simply have tithed the limited amount of produce in question to be on the safe side. That they sought and obtained rulings on such minor issues reflects the fact that the interaction of life and law will almost certainly produce more law, leading to significant complication over the long run.

Finally, tithing lacks much of the incoherence that marks most modern income taxes because it avoids provisions unrelated to income measurement. This is not to say that the rules of tithing are completely coherent. For instance, as described above, those who bring produce into the house through the front door are subject to tithe, while those who bring it into the house by some other means are not. ${ }^{190}$ This different treatment does not stem from some underlying principle or meaningful difference, but from the fact that the rule, as stated, refers only to front doors and does not expressly cover other means of entry. Thus, incoherence can and does arise from a literalist approach to the law. Nonetheless, the extent of such incoherence in the laws 
of tithing seems quite low when compared to that caused by the inclusion of non-tax objectives in most tax codes.

To be fair, agricultural tithing contains some complexity that would not likely exist in a modern income-based tax system. For instance, the use of money as the underlying measure of value in modern tax systems obviates the measurement problems associated with commodities and in-kind tithing. Perhaps more important, modern tax statutes and regulations can be amended easily to address new situations, while the Bible, the Mishnah and the Talmud cannot. The Torah is notoriously "thin" in some areas and "thick" in others, ${ }^{191}$ such that those seeking to apply the rules to unanticipated developments must often argue by attenuated analogy and inference, citing authorities that are not obviously addressed to the issues at hand. Such arguments may be quite difficult to follow and lead to a sense of incoherence that one would not likely see in a system where the statutes and regulations can easily be amended.

Nonetheless, even if one were to design an income-based consumption tax that avoided intractability and minimized incoherence by avoiding provisions that spring from non-tax policies or politics, the example of agricultural tithing lends support to the notion that truly simple tax systems are not likely to arise, even under the best circumstances.

\section{The Practical Approach}

In contrast to the theoretical approach, a number of scholars have sought to explore in detail how various income-based consumption taxes might be implemented. For instance, Michael J. Graetz examined how a hypothetical progressive "expenditure" tax might work, where consumption is measured by first determining income and then subtracting savings. ${ }^{192}$ He concluded that significant implementation and administrability issues would likely surface were such a tax ever adopted. ${ }^{193}$

David A. Weisbach has explored how both the Hall-Rabushka Flat Tax and X-Tax might be implemented. ${ }^{194}$ Among other things, he considered the difficulties of distinguishing between returns to labor and returns to capital, the ability to avoid the transition tax that would be imposed on existing capital

191. Jerusalem Talmud, Rosh Hashana Ch. 3, 59 (Edward A. Goldman trans., 1988).

192. Graetz, supra note 7, at 1580. See also Paul, supra note 183, at 200-01 (describing how and why complexity would arise in a progressive consumption tax system).

193. Graetz, supra note 7, at 1659-61.

194. Weisbach, Ironing out the Flat Tax, supra note 7, at 600; Weisbach, Does the X-Tax Mark the Spot?, supra note 7, at 202-03. 
were the U.S. to abandon its income tax in favor of a consumption tax, complexities related to financial transactions, losses and the structure of the business tax, accounting methods, international transactions, and small businesses. He noted that the first four of these issues form the core of most modern business tax planning, and therefore are responsible for much of the complexity of current tax law. ${ }^{195}$ While the extent of any complexity will depend on the ultimate form chosen for the tax, Professor Weisbach concluded that income-based consumption taxation will be more complex than one might initially think. ${ }^{196}$

In contrast, Daniel Shaviro has begun to explore how the political process might affect the implementation of a consumption tax. ${ }^{197}$ He first describes the political scenarios that might lead to the adoption of a consumption tax and then forecasts the type of consumption tax that would be most likely to develop from each identified scenario. He then identifies the design features that are likely to arise from such scenarios. Included in the list of potentially complicating design features are special treatment for home ownership, charitable contributions, state and local taxes and tax-exempt financing, pension and other retirement programs, health insurance and healthcare, educational expenses, and oil and gas. Thus, even if an ideal consumption tax might be simpler than the current tax system, he concludes that accommodating politically unavoidable deviations from the ideal will likely increase the complexity of any consumption tax. ${ }^{198}$

Finally, Professor Weisbach noted that the individual tax on wages will be less complicated than the current income tax because of the limited nature of that income. While he is certainly correct, he conceded in a footnote that the wage tax may "significantly increase complexity." 199 Insofar as taxpayers will have significant incentives to disguise wages and, to the extent that progressive rates are used, to assign income to others in lower tax brackets, significant complexity may result. To the extent that Congress enacts exemptions or deductions for items such as home mortgages and the sorts of social policy concerns Professor Shaviro identifies, even more complexity will exist. While Professor Weisbach noted that some of this complication may be

195. Weisbach, Ironing out the Flat Tax, supra note 7, at 624.

196. Id. at 661-62. Professor Weisbach also noted that, depending on how the tax is constructed, it may be avoidable, thus reducing its vaunted efficiency. $I d$. at 601 .

197. See Shaviro, supra note 7, at 5, 18.

198. Id. at $18-24$.

199. Weisbach, Does the X-Tax Mark the Spot?, supra note 7. 
avoidable through the use of a credit system, such a credit system will likely have its own set of issues.

While these analyses are critical if we are serious about implementing a consumption tax, they are not necessary to draw the conclusion that incomebased consumption taxes will be far more complex than is often suggested in the popular press. Indeed, many of the complicating factors Professor Weisbach identifies as likely to arise in a modern income-based consumption tax can be found in tithing. For instance, questions regarding the extent of Israel or the treatment of produce grown on the border are analogous to problems that might arise in any system that excludes income from foreign sources or denies deductions for expenses paid to foreign recipients. The requirement that one keep track of produce to ensure that it is properly tithed and that the various offerings are not inadvertently consumed by the wrong party mirror the need to keep financial records in any cash-flow system, and in particular in a system where the source of income or the nature of expenses matters, such as any destination basis system. ${ }^{200}$ The complications and inefficiency that will arise from efforts to evade the tax and to stop such evasion mirror similar issues that arise when farmers seek to avoid the tithe.

This is not meant to suggest that consumption taxation might not deliver meaningful simplicity gains over the current income tax. However, to the extent that history is any guide, the Jewish experience with tithing suggests that any income-based consumption tax will have its own complexities.

\section{Conclusion}

On the surface, the idea underlying agricultural tithing seems fairly straightforward: Separate out 10 percent of your produce and use it as directed in the Torah. Indeed, much of what contributes to complexity in our current tax system and in many of the popular income-based consumption tax proposals is avoided. Nonetheless, as demonstrated above, the rules of tithing are quite complex. The simple truth is that questions of income definition, including inclusion, deductions and timing, will arise in any income-based tax system, whether a true income tax or a consumption tax that uses income as a proxy for consumption. It is therefore to be expected that most - though not necessarily all —of the complexity associated with such issues will manifest itself in any such system. This fact holds an important lesson for us as we

200. In a destination basis system, sales abroad are excluded and no deductions are allowed for purchases from abroad. Weisbach, Does the X-Tax Mark the Spot?, supra note 7, at 211. 
think about ways to simplify the current income tax or replace it with a consumption tax.

Various writers have used Biblical imagery to describe taxation and efforts to create a simple tax code, using phrases such as "Promised Land," "Holy Grail" and "taxation's Garden of Eden." 201 The lesson to be drawn from agricultural tithing is that one need not stray far from Eden (either geographically or temporally) to end up with an extremely complicated tax. Indeed, even in the Promised Land, with one flat rate and no deductions, income-based taxes are complicated. In other words, given the nature of the enterprise, simplification efforts may not bear fruit, and the goal of simplification, whether by reforming the current income tax or replacing it with an income-based consumption tax, may be more aspirational than achievable.

201. Kenseth v. Comm'r, 259 F.3d 881, 884 (7th Cir. 2001) (referring to "taxation's Garden of Eden"); Johnson, supra note 3, at 578 (describing the desire to replace income taxation as based on "fanciful notions of a new Promised Land of taxation"); McCaffery, supra note 2. See also Richard L. Haight, Taxes in Paradise: Developing Basic Income Tax Concepts (2d ed. 2005). 